\title{
Patterns in the biodiversity of terrestrial environments in the southern Carnarvon Basin, Western Australia
}

\author{
N.L. McKenzie, G.J. Keighery, N. Gibson and J.K. Rolfe \\ Department of Conservation and Land Management, PO Box 51 \\ Wanneroo, Western Australia 6065, Australia
}

\begin{abstract}
Sixty-three quadrats each of 16 ha were chosen to represent the geographical extent and diversity of terrestrial environments in a $75000 \mathrm{~km}^{2}$ area of the Carnarvon Basin, Western Australia. A total of 626 plant and 456 animal species were recorded from the quadrats, an average of 120 (s.d. = 22.1) species per quadrat.

After species that occurred at only one quadrat and species for which the sampling methods were unreliable (e.g. snakes and raptors) were removed from the data-set, 730 species remained, an average of 108.6 per quadrat (s.d. $=20.1$ ). These comprised 81 herpetofauna, 13 small ground mammals, 85 birds, 9 scorpions, 12 centipedes, 122 ground-dwelling spiders and 408 plants.

The data were compiled into a single matrix comprising the presence or absence of the 731 species at the quadrats. When the species were classified according to their co-occurrences, thirteen assemblages were distinguished. Each assemblage could be characterised in terms of the Australia-wide habitat preferences of its component species. Also, quadrat similarity matrices were generated for each of the seven types of organism sampled and 1000 random matrices. These were output as linear similarity vectors so that the differences in their biodiversity patterns could be quantified as a single matrix of correlation coefficients.

Analyses revealed that:

1. Geographical patterns in species composition derived from the combined matrix correlated with processes operating at both biogeographical and local (ecological) scales: the compositional structure of each assemblage was related to a different set of climatic plus soil and/or topographic attributes. Poisson error models with logarithmic links fitted the gradient in species richness of each assemblage across the study area. Similar environmental attributes emerged whether an assemblage's composition or its richness was analysed. Since these attribute-sets were also consistent with the assemblages' Australia-wide characterisations, they are unlikely to be artifacts of quadrat positioning or study area extent.

2. Each of the seven ecologically different types of organism had a distinct influence on the biodiversity model; cross-taxon congruence levels were low.

To be representative, a Carnarvon Basin reserve system should sample the geographical range of the various climatic, soil and topographic gradients identified by the analyses. It should also be designed using a biodiversity model that incorporates a wide range of organisms.
\end{abstract}

\section{INTRODUCTION}

In this paper we explore geographical patterns in the composition of communities in non-aquatic environments of the southern Carnarvon Basin (Figure 1). The only previous attempt to define patterns in the biota of the study area was by Beard (1976), who mapped vegetation units at a scale of $1: 1000000$ from base maps compiled at $1: 250000$.

Our aims were to

- provide an overview of the composition and distribution of species assemblages, as components of communities,
- investigate the relationships between assemblage composition and measurable attributes of the study area's physical environment, to identify predictors of geographic patterns in species composition across the study area and

- examine levels of cross-taxon complimentarity (sensu Howard et al., 1998) in the study area, as a potential issue in reserve selection (McKenzie et al., 2000a).

We aimed to provide a regional context for conserving the study area's biodiversity by 


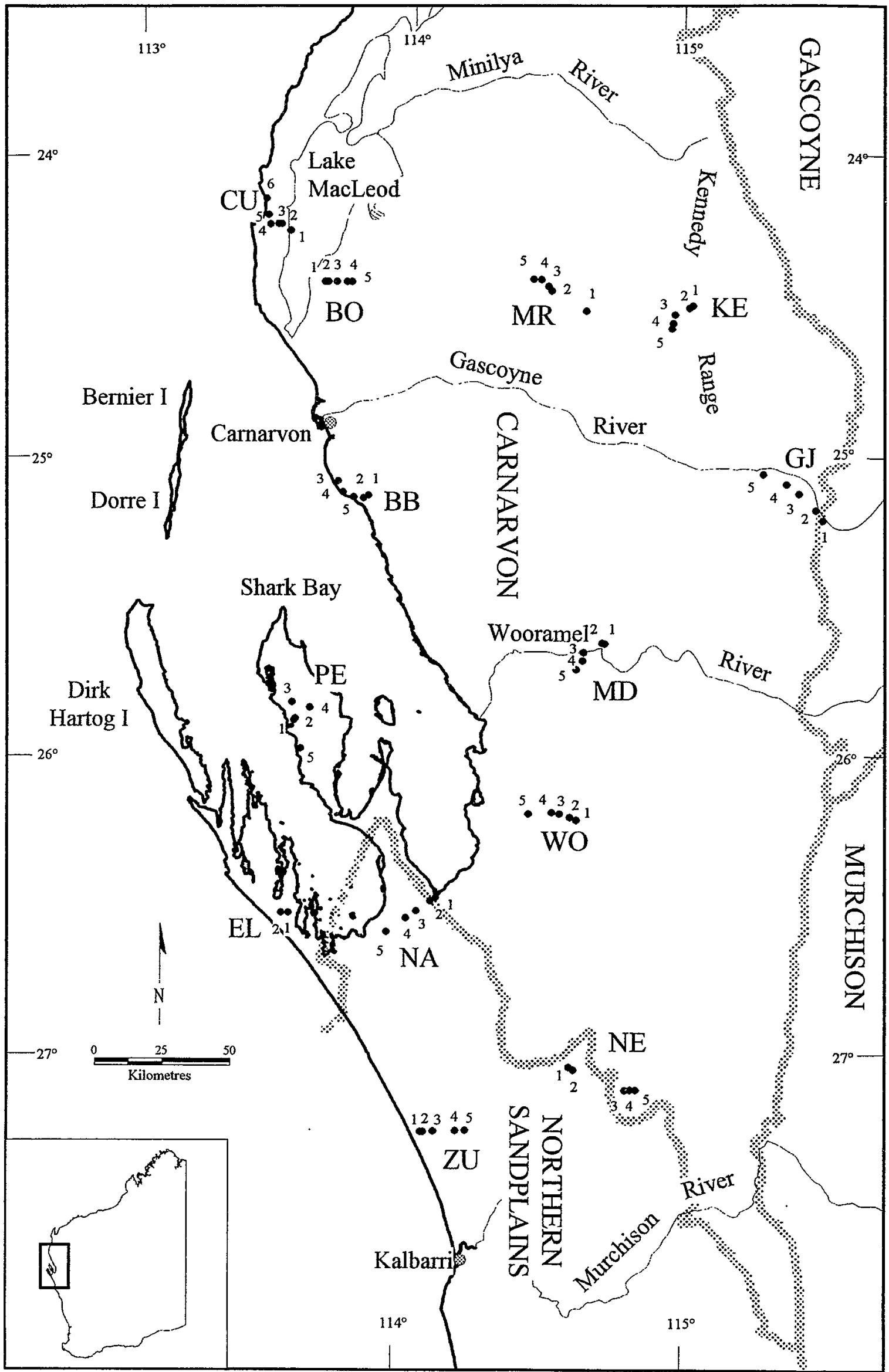

Figure 1 The Carnarvon Basin study area, showing the 13 survey areas (campsites) and individual quadrat positions. Precise quadrat co-ordinates are provided in Appendix A (this publication). The half-tone lines are the phytogeographic District boundaries of Beard (1980). 
analysing data on seven ecologically distinct types of organisms from 63 quadrats,

- positioned to represent the diversity of the study area's physical environments across its geographical extent, and

- defined in terms of a wide array of measured physical attributes that were related to both regional and local scales.

Spatial patterns in biodiversity have usually been examined in terms of subjective categorisations based on vegetation structure or soil type, or from the perspective of a narrow range of organisms (e.g. - plants or birds). We test the proposition that a more representative view of community patterns can be gained if a variety of ecologically distinct types of organism are sampled (Paine, 1980; Wiens, 1985; McKenzie et al., 1991a, b).

\section{METHODS}

\section{Study Area}

The Carnarvon Basin study area covers 75000 $\mathrm{km}^{2}$ on Australia's western coast. It is centred on Shark Bay, and extends northwards from the Murchison River to the Minilya River, and eastwards to beyond Gascoyne Junction (Figure 1).

Its physical environments are detailed by Wyrwoll, Stoneman, Elliott and Sandercock (2000) and Wyrwoll, Courtney and Sandercocck (2000). Briefly, the region is a lowland characterised by gentle gradients on a basement of soft sediments. Under a variety of climates, interacting alluvial and aeolian processes have produced a complex landscape mosaic, that has been further modified by extensive coastal transgressions associated with sea-level changes. Today, the area south of Shark Bay has a semi-arid climate influenced by temperate weather systems (mainly winter rainfall). From Shark Bay northward, the climate is influenced by both tropical and temperate systems - semi-arid at the coast, but arid with locally unreliable rainfall further inland that falls in both summer and winter. In phytogeographic terms, the study area comprises the northern half of the Irwin District of the Southwestern Province, as well as the southern half of the Carnarvon District of the Eremean Province (Beard, 1980).

Extensive alluvial plains dominate the study area, although erosional uplands such as the Kennedy Range occur in its eastern parts. The plains are traversed from east to west by two large, ephemeral rivers lined with groves of River Gum (Eucalyptus camaldulensis and E. victrix): the Gascoyne and Wooramel. Low open woodlands of bowgada (Acacia linophylla) and snakewood (A. xiphophylla) over Atriplex, Senna and Eremophila shrubs and tussock grasses cover the plains, with Acacia grasbyi in areas where calcretes are exposed. Low red sand ridges scattered across the plains support shrubs over mainly hummock-grasses. In northern parts, the plains grade into red sand dune fields that support hummock-grass and mulga ( $A$. aneura) communities reminiscent of Australia's 'red centre'. In the south the plains support woodlands of Eucalyptus loxophleba and Callitris glaucophylla, with mallee, Banksia, Allocasuarina and Actinostrobus scrubs and heaths on greyish and yellow sand dunes. A strip of limestone that follows the coast southwards from Shark Bay is partially mantled by pale yellow to grey sands supporting low proteaceous heaths with emergent thickets of Banksia and mallees such as Eucalyptus erythrocorys. White coastal sand dunes support Spinifex longifolius communities. Low-lying saline areas, such as the fringes of Lake MacLeod and the coastal flats, support samphire and saltbush communities. Descriptions of the vegetation in the study area are provided by Beard (1975, 1976), Payne et al. (1987), Gibson et al. (2000) and Keighery et al. (2000).

\section{Sampling Strategy}

Scale, complexity and patchiness need to be taken into account in sampling the biota of a study area to describe the diversity of its patterns (Braithwaite, 1984; Bowers, 1997).

A variety of factors can distort the results, including

- geographical and seasonal sampling bias (Braithwaite, 1984; Weins, 1985; Rosenzweig and Abramski, 1986),

- historic extinctions and introductions, and storage effects (Burbidge and McKenzie, 1989; Warner and Chesson, 1985),

- limitations in scale (Dale, 1983; Whitmore, 1984, p. 231; Bowers, 1997; MacNally and Quinn, 1997),

- inefficient sampling methods (Hobbs et al., 1984; Rolfe and McKenzie, 2000), including the analytical implications of unreliable 'absence' data in the presence-absence matrix (Margules and Austin, 1994),

- the assumption that guilds follow taxonomic boundaries (Adams, 1985; Bowers, 1997; McKenzie and Rolfe, 1986),

- uneven taxonomic resolution (see McKenzie et al. 2000b), and

- strongly localised patterns of endemism (Solem and McKenzie, 1991).

Aspects of the survey design (details are provided in Keighery et al., 2000; Harvey et al., 2000; McKenzie et al. 2000b) offset some of these problems.

- The study area was large enough to encompass significant sections of both the geographical and environmental ranges of the species sampled (Austin and Heyligers, 1989). 
- Sampling was carried out during an integrated programme; all quadrats were sampled in several seasons.

- The quadrat-size (16 ha for the zoological groups, and enclosing an 0.09 ha plant quadrat) was large enough to encompass the assemblages of the organisms being sampled considering their mobility, longevity and body-size in the context of their density, productivity and standing biomass in the study area. At the same time, the quadrats had to be small enough to allow the assumption that there was a reasonable level of internal homogeneity, and that there was syntopy between all biophysical attributes recorded within each quadrat (McKenzie et al., 1991b).

- Environmental attributes that reflect processes operating at both regional scales and local scales were measured for each quadrat.

- Our quadrats were sampled for perennial and annual plants, birds, frogs and lizards, small ground mammals, ground-dwelling spiders, centipedes, and scorpions. Thus, wide ranges in mobility, longevity, daily energy and moisture requirement, nutritional role, biomass and reproductive strategy were represented in the data-base, and guilds were less likely to be fragmented or severed along taxonomic boundaries.

- Tested sampling methods were applied by experienced field survey ecologists, and species were only included in the analysis if they were reliably captured by the sampling methods (see Burbidge et al., 2000, and Rolfe and McKenzie, 2000); thus the problems of unreliable 'absence' data in the presence-absence matrix were minimised.

- All specimen identifications were carried out by professional taxonomists familiar with the relevant group in Western Australia.

Quadrats were positioned throughout the geographical extent of the study area in a stratified random array derived from vegetation and surface lithology maps (Beard, 1976; Hocking et al., 1987). They were placed in typical examples of each of the main lithological units that characterise the study area, and positioned in clusters that were reasonably evenly dispersed across the study area's areal extent. The relative number of quadrats within a surface unit was roughly proportional to the unit's aerial extent in the study area. Many quadrats were pseudo-replicated (locally as well as at distant points) to allow for the internal heterogeneity of the stratification units (hypothesised scalars) and to minimise any analytical circularity introduced by the stratification (Taylor and Friend, 1984; McKenzie et al., 1989, 1991b).

\section{Field Sampling}

Quadrat locations and sampling procedures for the various taxa are provided elsewhere (Keighery et al., 2000; Burbidge et al., 2000; McKenzie et al., 2000b; Harvey et al., 2000). Briefly, species were sampled from 63 quadrats clustered in sets of two to six quadrats around each of 13 survey areas. Sampling was sparse. The study area encompassed 7.5 million hectares, and less than 1008 hectares was actually sampled (each quadrat was a releve' of $400 \times 400 \mathrm{~m}=16$ hectares, and 63 quadrats $\times 16$ ha $=1008$ ha). Thus, less than $0.013 \%$ of study area was actually sampled for animals. Furthermore, only a $30 \times 30 \mathrm{~m}$ area of each terrestrial quadrat was sampled for plants $(0.0001 \%$ of the study area).

\section{Analysis of Spatial Patterns in Species Assemblages}

The survey design was based on quadrat sampling and 'assemblage-connectance' concepts (May, 1975). The analytical approach taken in this paper was based on the assumption that spatial distribution reflects an underlying correlation with environmental factors (Austin, 1991; Clarke, 1993). It is, however, an exploratory design. No experimental design has been implemented to confirm a null hypothesis (Austin and McKenzie, 1988), so alternative hypotheses are not excluded.

The input data was the "quadrat-x-species" matrix. We determined and analysed the presence and absence of species on the quadrats, rather than their relative abundance, because limitations in sampling techniques, aggravated by staff and time limitations, precluded reliable estimates of abundance (Austin, 1984; McKenzie et al., 1991b).

We used cluster analysis (from PATN, Belbin, 1995) to expose patterns of species composition in the data matrices. The clustering techniques selected were described in McKenzie et al. (1991a). Briefly, the association measure "Two-step" (Belbin, 1980) was used to determine the quantitative relationship between each pair of species, and the Czekanowski measure (Czekanowski, 1932) was used to compare the quadrats according to their species similarities. For both measures of association, a modified version of "unweighted pair group arithmetic averaging" (UPGMA - Sneath and Sokal, 1973; Belbin, 1995) hierarchial clustering strategy was used, with the clustering parameter (Beta) set to -0.1.

A modification by Hubert and Arabie (1985) of the statistic by Rand (1971) was used to compare the classification partition structures derived from different data-sets [RIND module in PATN (Belbin, 1995)].

Further analysis was carried out in the following order:

1. The data matrix was partitioned into 
Table 1 Vegetation attributes used to summarise the 'type' and structure (-stru) of the vegetation on the quadrats in ordinal terms.

\begin{tabular}{ll}
\hline Veg-stru & Veg-type \\
\hline $\begin{array}{c}\text { Grass and /or low shrubs }=1 \\
+ \text { Shrubs to } 1.5 \mathrm{~m} \text { high }=2\end{array}$ & Grass and/or low shrubs $=1$ \\
$\quad+$ tall shrubs $(1.5$ to $3 \mathrm{~m}$ high $)=3$ & Shrubland $=2$ \\
$\quad+$ low trees and /or mallees $=4$ & Tall Shrubland $=3$ \\
$\quad+$ trees $>8 \mathrm{~m}$ high $=5$ & Low Woodland: Acacia canopy $=4$ \\
& Woodland: mixed canopy $=5$ \\
& Woodland: Eucalyptus canopy $=6$ \\
\hline
\end{tabular}

assemblages of species according to their cooccurrences at the same quadrats.

2. Each assemblage was characterised in terms of the known habitat preferences of its component species throughout their ranges elsewhere in Australia (Strahan, 1995; Wilson and Knowles, 1988; Ehmann, 1992; Tyler et al., 1994; Jessop, 1981; Koch, 1981; Pizzey, 1980, as well as reviews in earlier papers in this volume).

3. Quadrats were classified according to similarities in the species composition (as above), to summarise each assemblage's pattern of occurrence across the study area in the form of a separate dendrogram (its compositional structure). Next, each dendrogram was analysed in terms of a set of attributes related to the physical environment of the quadrats (see Wyrwoll, Stoneman, Elliott and Sandercock (2000), Wyrwoll, Courtney and Sandercock (2000) and Appendix D, this publication). In this analysis, univariate data on aspects of the quadrats' physical environments were superimposed as a histogram on each dendrogram, attribute-by-attribute. This process allowed us to identify the physical attributes that most closely conformed with each dendrogram's partition structure, i.e. the pattern of its species-composition across the study area. The statistical significance of relationships was assessed using Kruskal-Wallis one way analysis of variance by ranks (the GSTA module in PATN - Belbin, 1995).

4. The generalised linear interactive modelling package GLIM (NAG, 1986; Nicholls, 1989) was used to model the relationships between the species richness of each assemblage and the physical attributes of the quadrats. Forward, stepwise regression models were fitted to each of the species-assemblages defined from the classification procedure, with quadrat speciesrichness as the dependent variable. The significance of the parameters in the regression equations was calculated using the Wald statistic, and is indicated by asterisks (* $=$ significant at $>0.05, * *>0.01, * *>0.001$ etc).

Eleven climatic attributes were derived for each quadrat using ANUCLIM (McMahon et al., 1995). Soil and geomorphic attributes were also recorded from each quadrat (Wyrwoll, Stoneman, Elliott and Sandercock, 2000). The 17 soil chemical and texture values used herein were derived from sub-samples collected at a depth of 5-10 cm from 20-30 regularly dispersed points on each quadrat, then bulked (Appendix D). Two vegetation attributes were also generated: 'veg-type' and 'veg-stru' (defined in Table 1). Significant correlations between these

Table 2 Environmental attribute codes.

\begin{tabular}{llll}
\hline Code & Attribute & Code & Attribute \\
\hline Pann & Annual average precipitation $(\mathrm{mm})$ & $\mathrm{Cl}$ & Soil chloride $(\%)$ \\
Pcld & Coldest quarter precipitation $(\mathrm{mm})$ & exNa & Exchangeable sodium $(\mathrm{me} \%)$ \\
Pwet & Wettest quarter precipitation $(\mathrm{mm})$ & $\mathrm{EC}$ & Electrical conductivity $(\mathrm{mS} / \mathrm{m})$ \\
Pwp & Wettest period precipitation $(\mathrm{mm})$ & exMg & Exchangeable magnesium $(\mathrm{me})$ \\
Pwar & Warmest quarter precipitation $(\mathrm{mm})$ & $\mathrm{N}$ & Total nitrogen $(\mathrm{ppm})$ \\
Psea & Precipitation seasonality & exK & Exchangeable potassium $(\mathrm{me} \%)$ \\
Tann & Annual average temperature $\left({ }^{\circ} \mathrm{C}\right)$ & $\mathrm{K}\left(\mathrm{HCO}_{3}\right)$ & Available potassium $(\mathrm{ppm})$ \\
Twet & Wettest quarter mean temperature $\left({ }^{\circ} \mathrm{C}\right)$ & $\mathrm{P}$ & Total phosphorus $(\mathrm{ppm})$ \\
Tcld & Coldest quarter mean temperature $\left({ }^{\circ} \mathrm{C}\right)$ & $\mathrm{P}(\mathrm{HCO})$ & Available phosphorus $(\mathrm{ppm})$ \\
Twar & Warmest quarter mean temperature $\left({ }^{\circ} \mathrm{C}\right)$ & $\mathrm{CaCO}$ & Calcium Carbonate $(\%)$ \\
Tdi & Temperature diurnal range $\left({ }^{\circ} \mathrm{C}\right)$ & $\mathrm{CEC}$ & Cation exchange capacity $(\mathrm{me} \%)$ \\
Tar & Temperature annual range $\left({ }^{\circ} \mathrm{C}\right)$ & tx-shst & Soil textural shear strength $(\mathrm{kPa})$ \\
Cst-dist & Distance to coast $(\mathrm{km})$ & Stone & Amount of rock in soil profile \\
Alt & Altitude $(\mathrm{m})$ & Sand & Percent sand \\
Lat & Latitude $\left({ }^{\circ} \mathrm{S}\right)$ & gs-over & Over-bank stream flow \\
Long & Longitude $\left({ }^{\circ} \mathrm{E}\right)$ & Veg-type & see Table 1. \\
& & Veg-stru & see Table 1. \\
\hline
\end{tabular}


physical attributes were identified using Kendall's rank correlation coefficient (Kendall's tau). Physical attribute names and codes are listed in Table 2.

\section{Influence of the Taxonomic Sub-sets on the Biodiversity Model}

Our analytical strategy was similar to that used by Somerfield and Clarke (1995). Seven taxonomic sub-sets were represented in the community matrix: birds, small ground mammals, herpetofauna, ground-dwelling spiders, scorpions, centipedes and vascular plants. Analysis involved eight steps:

1. For each sub-set, and for the combined data-set, a dissimilarity matrix was derived by using the Czekanowski measure (Czekanowski, 1932, from the ASO module in Belbin, 1995) to compare quadrats in terms of their species composition.

2. Each dissimilarity matrix was output as a linear vector (Option 6 in the ASON module of PATN, Belbin, 1995).

3. Using Pearson Product-Moment Correlation, we calculated the correlation between each pair of vectors as a measure of congruence in their (spatial) biodiversity patterns. These correlation coefficients were compiled as a matrix of 'crosstaxon' congruence.

4. Next, the correlation matrix was converted to a dissimilarity matrix (1-coefficient), and Semistrong Hybrid Scaling (SSH in Belbin, 1995) was used to reduce the dimensionality of this matrix, so that the relationships between the sub-set patterns and the combined pattern (the biodiversity model) could be displayed in three dimensions.

5. A 'minimum spanning tree' (MST in Belbin, 1995) was superimposed to indicate the nearestneighbour linkages in the ordination space.

6. To provide some extrinsic measure of distance across the ordination space, 1000 uniform random matrices were generated and plotted in the same ordination space using the steps listed above.

\section{RESULTS}

Spatial Patterns in the Richness and Composition of Species Assemblages

A total of 626 plant and 456 animal species were recorded from the 63 quadrats, an average of 120 species per quadrat (s.d. $=22.1, \mathrm{n}=63$; Table 3 ). The animals comprised 133 herpetofauna (12 frogs, 121 reptiles), 15 small ground mammals, 126 birds, 10 scorpions, 15 centipedes and 157 grounddwelling spiders.

Quadrats on saline claypans (BB3, BO2, NA1, PE1, CU1) were poorest in species (average $=77$ species, s.d. $=25, n=5)$. Ignoring saline claypans, we also noted that

- quadrats that were being regularly grazed by stock, feral goats and/or rabbits at the time of our study were not significantly poorer in species than those that showed no sign of contemporary usage by these introduced herbivores (KE1-2, NA2-5, NE1, ZU1$5)(124.6 \pm 18.2, n=46$ versus $120.3 \pm 15.8, n=12$ respectively),

- even quadrats in overtly degraded condition, with sheet erosion and virtually no leaf litter or A1 soil-horizon remaining (BB1, BO5, GJ4-5, $\mathrm{KE4}$, MD1,2,4,5, PE4 and WO1,4) retained only marginally lower richness overall $(116.4 \pm 12.3$, $n=12$ versus $125.6 \pm 18.5, n=46$ ) and

- quadrats on deep red sands were the richest $(131.5 \pm 16.6, n=20)$.

Using the entire 1082 species, the 63 quadrats were classified in terms of similarities in their species composition. After species that occurred at only one quadrat and species for which the sampling methods were unreliable (e.g. raptors and snakes, see Burbidge et al., 2000 and McKenzie et al., $2000 \mathrm{~b}$ ) were removed from the data-set, 730 species remained (an average of 108.6 per quadrat, s.d. = 20.1). These comprised 10 frogs, 71 lizards, 13 small ground mammals, 85 birds, 9 scorpions, 12 centipedes, 122 ground-dwelling spiders and 408 plants. Using this reduced matrix, the 63 quadrats



Figure 2 Quadrats classified according to their species composition using the 731 species data-set. Dendrogram structure to the 12-group level is displayed. 
were again classified in terms of similarities in their species composition to yield a quadrat dendrogram that summarised geographical patterns of occurrence (Figure 2).

When the dendrogram partition structures derived from the 1082-species and the 730-species data-sets were compared using the modified RAND statistic (Table 4), the differences at the 12-group level were small (Hubert and Arabie RAND statistic $=0.96)$. Only two quadrats were assigned differently by the reduced data-set (CU1 and NA2).

The 730 species were classified according to similarities in their co-occurrences at the same quadrats. The 13 assemblages we defined are characterised in terms of the distributional characteristics and habitat preferences of their component species throughout their geographical ranges in Australia (Figure 3). Relevant annotations are on this dendrogram and additional notes are presented below.

\section{Distributions Centred on the Arid Zone}

Assemblage-1: Ubiquitous riverine species, such as River Gums. The dragon Gemmatophora longirostris also occurs in coastal dunes.

Assemblage-2: Species of fine-textured soils and associated lunettes. It comprises six species-subsets that formed distinct partitions at lower levels in the dendrogram:

2a. ubiquitous species;

$2 \mathrm{~b}$. species of fine-textured riverine alluvia;

2c. ubiquitous non-saline species;

$2 \mathrm{~d}$. species of saline playas or lunettes of playas, and of alluvial plains;

2e. species of semi-saline sandy lunettes in and around saline playas and claypans;

2f. species of sandy lunettes surrounded by extensive plains of fine-textured soils.

Unlike group $2 \mathrm{~d}$, species in ' $2 \mathrm{e}^{\prime}$ and ' $2 \mathrm{f}^{\prime}$ ' have localised occurrences in the study area.

Assemblage-3: Species of floodplains, footslopes

Table 3 Species richness per quadrat.

\begin{tabular}{lllllll}
\hline \multicolumn{2}{c}{ Campsite } & \multicolumn{6}{c}{ Quadrat } \\
& $\mathbf{1}$ & $\mathbf{2}$ & $\mathbf{3}$ & $\mathbf{4}$ & $\mathbf{5}$ & $\mathbf{6}$ \\
\hline BB & 112 & 123 & 108 & 137 & 125 & \\
BO & 136 & 87 & 161 & 160 & 136 & \\
CU & 63 & 126 & 124 & 122 & 131 & 107 \\
EL & 98 & 101 & & & & \\
GJ & 108 & 108 & 128 & 101 & 118 & \\
KE & 107 & 97 & 134 & 110 & 126 & \\
MD & 138 & 116 & 175 & 113 & 124 & \\
MR & 147 & 154 & 128 & 131 & 119 & \\
NA & 86 & 143 & 129 & 131 & 105 & \\
NE & 128 & 86 & 123 & 118 & 108 & \\
PE & 42 & 145 & 143 & 120 & 132 & \\
WO & 96 & 108 & 117 & 113 & 144 & \\
ZU & 103 & 131 & 137 & 104 & 129 & \\
\hline
\end{tabular}

and clayey interdune plains, i.e. of heavier soils than the species belonging to Assemblage-2. Some rock-outcrop species at ecotonal sites are included (e.g. Sminthopsis longicaudata and Ptilotus polakii were found at KE3 and GJ1 which straddled the lower slope and foot of scree slopes).

Assemblage-4: Specialists of deep red desert sand dunes and plains, including patches close to the coast. Some are centred on the Carnarvon Basin (e.g. Verticordia forrestii).

\section{Ubiquitous Distributions}

Assemblage-5: Species with distributions that cover arid, semi-arid and mesic regions, and which occur on all surfaces. Some even reach the mesic tropics (e.g. Black-faced Cuckoo-shrike, Euphorbia australis and Cenchrus ciliaris).

\section{Semi-arid Distributions}

Assemblage-6: Species with distributions centred on sand surfaces in the semi-arid.

Assemblage-7: Centred on semi-arid woodlands of (mainly) the temperate zone. Some extend into the arid zone in association with trees, such as along riverine fringes. Some birds reach the mesic tropics.

\section{Widespread Saline and Calcareous Plain Species}

Assemblage-8: Widespread claypan species, usually saline but also on chenopod plains with saltbush and/or bluebush. Some also occur in coastal areas adjacent to mangroves in Shark Bay. Scaevola crassifolia is an exception.

\section{Coastal Sand Distributions}

Assemblage-9: Specialists of coastal, semi-arid, sand surfaces in the temperate zone. Some are endemic to Edel Land.

Assemblage-10: Species of coastal, sub-tropical (northern), sand surfaces from Carnarvon to Exmouth $\left(22^{\circ} \mathrm{S}, 114^{\circ} \mathrm{E}\right)$, except for Triodia basedowei which also occurs on red sand surfaces of inland Australia, and T. pungens of red sand surfaces in the Pilbara, Little Sandy Desert, Great Sandy Desert, southern Kimberley and elsewhere in northern Australia.

\section{Distributions Centred on the Temperate Zone}

Assemblage-11: Three species sub-sets formed discrete partitions at a lower level in the dendrogram:-

11a. Specialists of temperate (southern) coastal areas. Exceptions are Solanum oldfieldii which extends further inland, Tiliqua rugosa which is not reliably detected by our survey methods and therefore is a sampling artifact, and Thick-billed Grass-wren whose extant distribution is an extinction artifact.

11b. Temperate semi-arid species of sandy and 


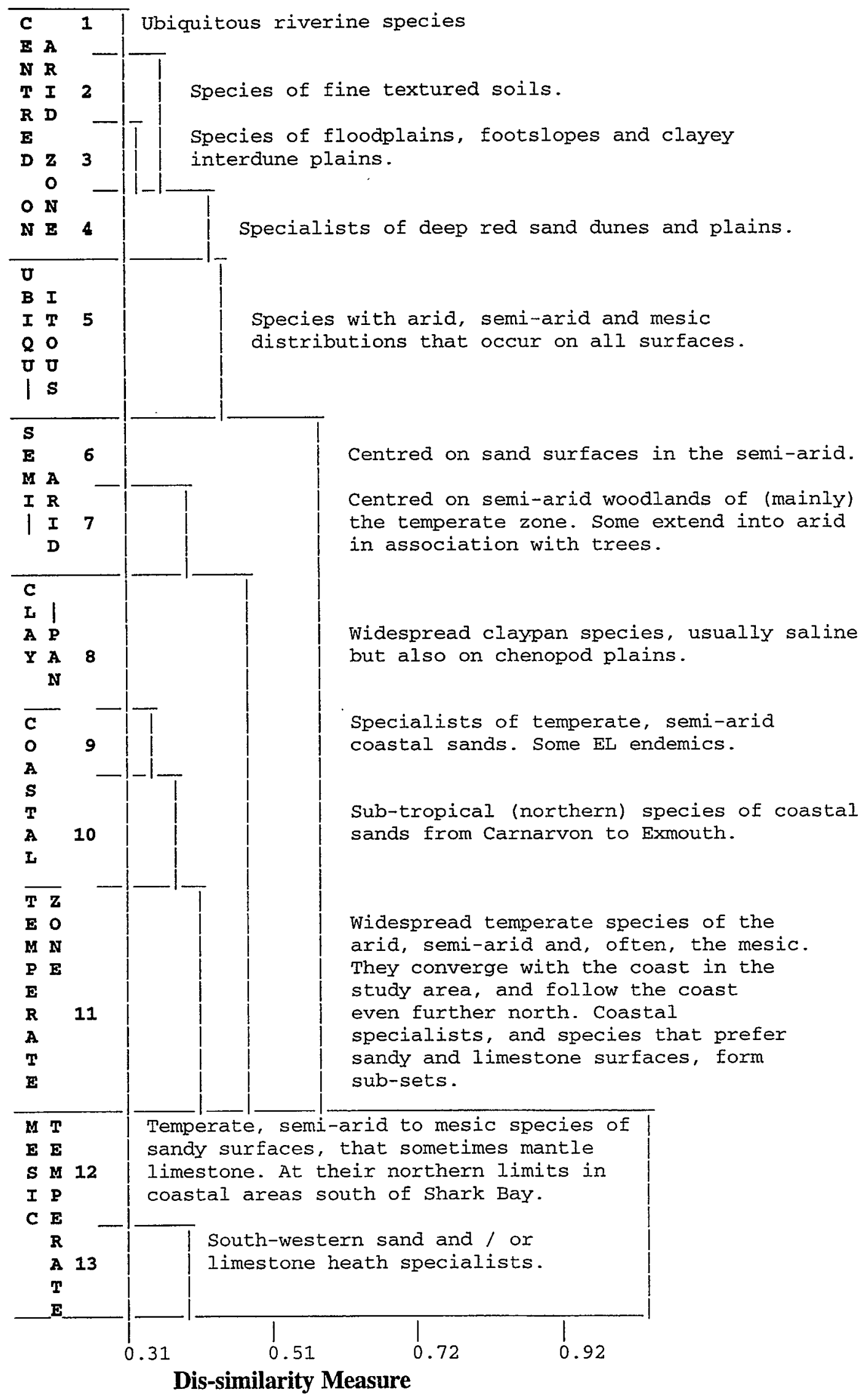

Figure 3 Species assemblages derived by classifying species according to their co-occurrences at the same quadrats. Dendrogram structure to the 13-group level is displayed. Assemblages are characterised in terms of the distributional characteristic and habitat preferences of their component species throughout their geographical ranges in Australia. 


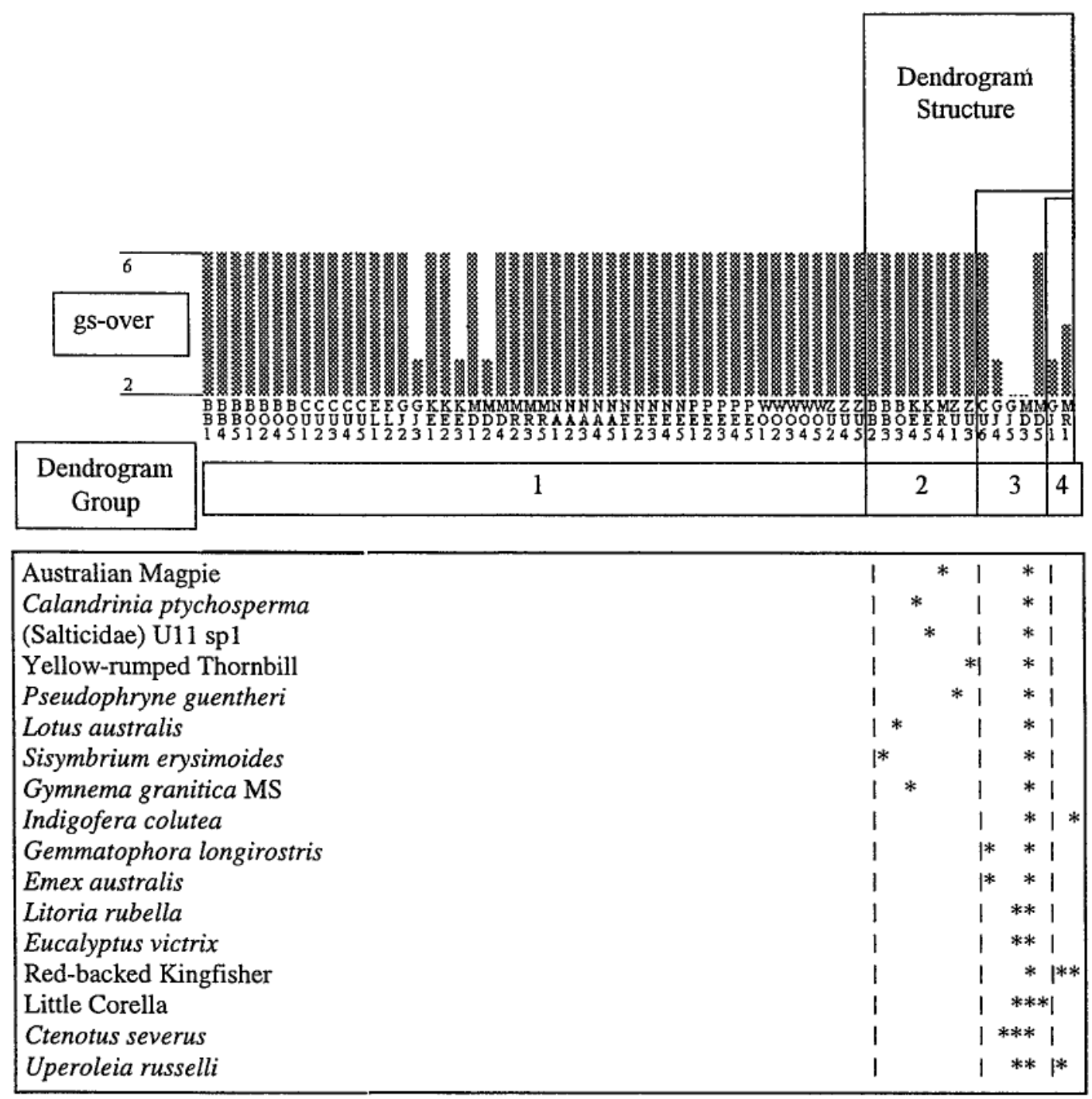

Figure 4 Attribute values for 'over-bank stream flow' (gs-over) superimposed as an histogram on the dendrogram structure derived from the classification of the 63 quadrats in terms of species belonging to assemblage- 1 . Quadrat codes are printed vertically. Values for gs-over ranged from 2 to 6 (see Wyrwoll, Courteney and Sandercock, 2000). The relevant re-ordered data matrix from Figure 12 is aligned beneath the histogram.

Table 4 Comparison between the quadrat classification partition derived from the 730 species data-set (Partition-1, see Figure 2) and the partition derived from the 1082 species data-set (Partition-2).

\begin{tabular}{|c|c|c|c|c|c|c|c|c|c|c|c|c|}
\hline \multirow[t]{2}{*}{ Partition-1 } & \multicolumn{12}{|c|}{ Partition-2 } \\
\hline & 1 & 2 & 3 & 4 & 5 & 6 & 7 & 9 & 8 & 10 & 11 & 12 \\
\hline 1 & 4 & 1 & - & - & - & - & - & - & - & - & - & - \\
\hline 2 & - & 1 & - & - & - & - & - & - & - & - & - & - \\
\hline 3 & - & - & 7 & - & - & - & - & - & - & - & - & - \\
\hline 4 & - & - & - & 11 & - & - & - & - & - & - & - & - \\
\hline 5 & - & - & - & - & 8 & - & - & - & - & - & - & - \\
\hline 6 & - & - & - & - & - & 6 & - & - & - & - & - & - \\
\hline 7 & - & - & - & - & - & - & 5 & - & - & - & - & - \\
\hline 8 & - & - & - & - & - & - & - & 2 & - & - & - & - \\
\hline 9 & - & - & - & - & - & - & - & - & 4 & 1 & - & - \\
\hline 10 & - & - & - & - & - & - & - & - & - & 4 & - & - \\
\hline 11 & - & - & - & - & - & - & - & - & - & - & 4 & - \\
\hline 12 & - & - & - & - & - & - & - & - & - & - & - & 5 \\
\hline
\end{tabular}

Hubert $/$ Arabie RAND statistic $=0.96$

Diagonal $/$ total $=61 / 63=0.97$ 
Table 5 Relationship between environmental attributes and geographical patterns in assemblage richness and composition. Environmental attribute codes are explained in Table 2, and detailed in Wyrwoll, Courteney and Sandercock, 2000). In all cases, poisson error models with logarithmic links best fitted the richness gradients. 'Test' lists the quadrat/s to which the fitted model was sensitive, and whether or not the model estimates changed significantly after the quadrat's influence was suppressed (Yes/No). 'Group Level' indicates the level at which the relevant quadrat dendrogram was cut (the number of partitions defined).

\begin{tabular}{|c|c|c|c|c|c|c|}
\hline $\begin{array}{l}\text { Assemblage } \\
\text { (from Fig. 3) }\end{array}$ & $\begin{array}{l}\text { Richness Gradient } \\
\text { Fitted Model: Ln(Richness) }= \\
\left({ }^{*}<.05,{ }^{* *}<.01 \text { etc }\right)\end{array}$ & Test & $\begin{array}{l}\text { Compo } \\
\text { Group } \\
\text { Level }\end{array}$ & $\begin{array}{l}\text { tional Struc } \\
\text { Attributes }\end{array}$ & $\begin{array}{l}\text { cture } \\
\text { Kruskal } \\
\text {-Wallis }\end{array}$ & Prob. \\
\hline 1 & $\begin{array}{l}-2.3-15.5 \text { exNa+4.6exMg } \\
\text { exNa and exMg }=* * * \\
\text { Scaled Deviance }=47 \text {, d.f. }=60 \\
\text { Scaled Deviance of Null Model }=156\end{array}$ & $\begin{array}{l}\text { MD3, } \\
\text { N }\end{array}$ & 4 & gs-overt & 17.9 & 0.0005 \\
\hline 2 & $\begin{array}{l}\text { 2.2-0.02Alt+0.004 Alt }{ }^{2}-0.02 \mathrm{Pwet}+ \\
\text { 0.009P-0.04CaCO }+0.24 \mathrm{Tdi} \\
\text { Alt, } \mathrm{Alt}^{2}, \text { Pwet, } \mathrm{P} \text { and } \mathrm{CaCO}_{3}=* * * ; \\
\text { Tdi }=* * \\
\text { Scaled Deviance }=132, \mathrm{~d} . \mathrm{f} .=57 \\
\text { Scaled Deviance of Null Model }=683\end{array}$ & $\begin{array}{l}\text { CU6, } \\
\mathrm{N}\end{array}$ & 358 & $\begin{array}{l}\text { Pwet } \\
\text { P } \\
\text { Tdi }\end{array}$ & $\begin{array}{l}32.3 \\
25.1 \\
36.1\end{array}$ & $\begin{array}{l}<0.0001 \\
<0.0001 \\
<0.0001\end{array}$ \\
\hline 3 & $\begin{array}{l}-37.6+1.4 \mathrm{Twar}-8 \mathrm{e}^{-5} \operatorname{Pann}^{2}+50.7 \mathrm{~N} \\
\text { Twar, Pann }{ }^{2} \text { and } \mathrm{N}=* * * * \\
\text { Scaled Deviance }=67.1, \text { d.f. }=59 \\
\text { Scaled Deviance of Null Model }=576\end{array}$ & $\begin{array}{l}\text { CU1, } \\
\mathrm{N}\end{array}$ & $\begin{array}{l}6 \\
6 \\
6\end{array}$ & $\begin{array}{l}\text { Twar } \\
\text { Pann } \\
\text { N }\end{array}$ & $\begin{array}{l}42.0 \\
33.8 \\
4.1\end{array}$ & $\begin{array}{l}<0.0001 \\
<0.0001 \\
0.5 \mathrm{NS}\end{array}$ \\
\hline 4 & $\begin{array}{l}-19.6+0.06 \mathrm{Pwar}-0.007 \mathrm{P}+0.61 \mathrm{Twar}- \\
0.0055 \mathrm{~K}\left(\mathrm{HCO}_{3}\right) \\
\text { Pwar and Twar }=* * * ; \mathrm{P} \text { and } \mathrm{K}\left(\mathrm{HCO}_{3}\right)=* * \\
\text { Scaled Deviance } 76.2, \text { d.f. }=58 \\
\text { Scaled Deviance of Null Model }=481\end{array}$ & $\begin{array}{l}\text { CU3, } \\
\mathrm{N}\end{array}$ & $\begin{array}{l}3 \\
7 \\
7\end{array}$ & $\begin{array}{l}\text { Pwar } \\
\text { Twar } \\
\mathrm{K}\left(\mathrm{HCO}_{3}\right)\end{array}$ & $\begin{array}{l}25.1 \\
27.5 \\
5.9\end{array}$ & $\begin{array}{l}<0.0001 \\
0.0001 \\
0.43 \mathrm{NS}\end{array}$ \\
\hline 5 & $\begin{array}{l}\text { 5.15-0.006Pwet-0.198exMg-0.002Alt- } \\
\text { 0.006CaCO } \\
\text { Pwet, exMg, Alt and } \mathrm{CaCO}_{3}=* * * * \\
\text { Scaled Deviance } 94.5, \text { d.f. }=58 \\
\text { Scaled Deviance of Null Model }=347\end{array}$ & $\begin{array}{l}\text { PE1, } \\
\text { N }\end{array}$ & $\begin{array}{l}6 \\
6 \\
11 \\
11\end{array}$ & $\begin{array}{l}\text { Psea } \\
\text { Alt } \\
\text { exMg } \\
\mathrm{CaCO}_{3}\end{array}$ & $\begin{array}{l}43.9 \\
26.3 \\
29.5 \\
37.9\end{array}$ & $\begin{array}{l}<0.0001 \\
0.0001 \\
0.001 \\
<0.0001\end{array}$ \\
\hline 6 & $\begin{array}{l}-0.55-9.07 \text { exK-0.216P( }\left(\mathrm{HCO}_{3}\right)+0.117 \mathrm{Psea}- \\
0.277 \mathrm{Pann} \\
\text { exK, } \mathrm{P}\left(\mathrm{HCO}_{3}\right) \text {, Psea and Pann }=* * * * \\
\text { Scaled Deviance } 88.3 \text {, d.f. }=58 \\
\text { Scaled Deviance of Null Model }=373\end{array}$ & $\begin{array}{l}\text { NA4, } \\
\text { N }\end{array}$ & $\begin{array}{l}4 \\
4 \\
9 \\
9\end{array}$ & $\begin{array}{l}\text { exK } \\
\text { Veg-type* } \\
\text { P } \\
\text { Psea }\end{array}$ & $\begin{array}{l}21.2 \\
20.3 \\
26.6 \\
15.2\end{array}$ & $\begin{array}{l}0.0001 \\
0.0002 \\
0.0008 \\
0.055\end{array}$ \\
\hline 7 & $\begin{array}{l}-59.3-0.12 \mathrm{P}\left(\mathrm{HCO}_{3}\right)+0.61 \mathrm{Pcld}-0.00094 \mathrm{Pcld}^{2}- \\
0.36 \mathrm{Pwet}+2.30 \mathrm{Tann} \\
\mathrm{P}^{2}\left(\mathrm{HCO}_{3}\right), \text { Pcld, Pcld } \\
\text { Scaled Pwet Deviance } 125.1 \text {, d.f. }=57 \\
\text { Scaled Deviance of Null Model }=505\end{array}$ & $\begin{array}{l}\text { ZU1, } \\
\mathrm{N}\end{array}$ & $\begin{array}{l}6 \\
6\end{array}$ & $\begin{array}{l}\text { Veg-type* } \\
\text { Tcld }\end{array}$ & $\begin{array}{l}26.3 \\
16.7\end{array}$ & $\begin{array}{l}0.0001 \\
0.005\end{array}$ \\
\hline 8 & 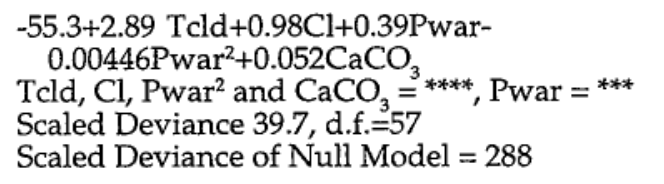 & $\begin{array}{l}\text { PE1, } \\
\text { N }\end{array}$ & $\begin{array}{l}4 \\
4 \\
4 \\
6 \\
6\end{array}$ & $\begin{array}{l}\mathrm{Cl} \\
\mathrm{P}\left(\mathrm{HCO}_{3}\right) \\
\text { Alt } \\
\text { exMg } \\
\mathrm{CaCO}_{3}\end{array}$ & $\begin{array}{l}25.6 \\
23.4 \\
19.8 \\
13.0 \\
18.9\end{array}$ & $\begin{array}{l}<0.0001 \\
<0.0001 \\
0.0002 \\
0.024 \\
0.002\end{array}$ \\
\hline 9 & $\begin{array}{l}-6.47+0.037 \mathrm{CaCO}_{3}+0.071 \mathrm{Pwp} \\
\mathrm{CaCO}_{3}=* * * *, \mathrm{Pwp}=* * \\
\mathrm{Scaled}^{*} \text { Deviance }=30.1, \text { d.f. }=60 \\
\text { Scaled Deviance of Null Model }=131\end{array}$ & $\begin{array}{l}\text { ZU2, } \\
\mathrm{N}\end{array}$ & $\begin{array}{l}2 \\
4\end{array}$ & $\begin{array}{l}\mathrm{Pwp} \\
\mathrm{CaCO}_{3}\end{array}$ & $\begin{array}{l}8.3 \\
10.7\end{array}$ & $\begin{array}{l}0.0041 \\
0.0133\end{array}$ \\
\hline 10 & $\begin{array}{l}\text { 73.4-4.27Lat }+0.27 \mathrm{Pwp}-0.15 \mathrm{P}\left(\mathrm{HCO}_{3}\right)+0.71 \mathrm{Tar} \\
\text { Lat, Pwp and } \mathrm{P}\left(\mathrm{HCO}_{3}\right)=* * * *, \mathrm{Tar}^{*}=* \\
\text { Scaled Deviance }=33.2 \text {, d.f. }=58 \\
\text { Scaled Deviance of Null Model }=278\end{array}$ & $\begin{array}{l}\text { CU5, } \\
\mathrm{N}\end{array}$ & $\begin{array}{l}7 \\
7 \\
7\end{array}$ & $\begin{array}{l}\text { Lat } \\
\mathrm{P}\left(\mathrm{HCO}_{3}\right) \\
\text { Tdi }\end{array}$ & $\begin{array}{l}20.5 \\
10.6 \\
16.2\end{array}$ & $\begin{array}{l}0.002 \\
0.10 \mathrm{NS} \\
0.013\end{array}$ \\
\hline 11 & $\begin{array}{l}\text { 18440-323.2Long-0.24Tann }{ }^{2}-4.11 \mathrm{exK}+ \\
\text { 1.41 } \mathrm{Long}^{2}-0.0088 \mathrm{CaCO}_{3}+9.80 \mathrm{Tann}+ \\
5.57 \mathrm{exK}^{2}-0.21 \mathrm{exNa} \\
\text { exK } \mathrm{K}^{2} \text { and Tann }=* * * \text { all others }= \\
\text { Scaled Deviance }=91.4 \text {, d.f. }=54 \\
\text { Scaled Deviance of Null Model }=828\end{array}$ & $\begin{array}{l}\text { PE1, } \\
\text { N }\end{array}$ & $\begin{array}{l}8 \\
8 \\
8 \\
6\end{array}$ & $\begin{array}{l}\text { Pcld } \\
\text { Cst-dist } \\
\text { exK } \\
\text { exNa }\end{array}$ & $\begin{array}{l}37.9 \\
38.1 \\
40.2 \\
17.1\end{array}$ & $\begin{array}{l}<0.0001 \\
<0.0001 \\
<0.0001 \\
0.0044\end{array}$ \\
\hline 12 & $\begin{array}{l}-24.6+0.027 \mathrm{Pann}+0.32 \text { Sand }-0.78 \mathrm{Tcld}+ \\
0.051 \mathrm{CEC}^{2} \text { Pann and Sand }=* * * *, \text { Tcld }=* * \\
\mathrm{CEC}^{2}=* \\
\text { Scaled Deviance }=54.7 \text {, d.f. }=58 \\
\text { Scaled Deviance of Null Model }=824\end{array}$ & $\begin{array}{l}\text { ZU5, } \\
\mathrm{N}\end{array}$ & 5 & Pcld & 22.9 & 0.0001 \\
\hline 13 & $\begin{array}{l}\text { Entire assemblage is either present or } \\
\text { absent, so model will not converge. }\end{array}$ & - & $\begin{array}{l}2 \\
2\end{array}$ & $\begin{array}{l}\text { Stone } \\
\text { Pcld }\end{array}$ & $\begin{array}{l}9.5 \\
5.7\end{array}$ & $\begin{array}{l}0.002 \\
0.017\end{array}$ \\
\hline
\end{tabular}

t Ordinal data, not used in the GLM analysis. 
limestone surfaces. They centre on the mid-latitude coast; many extend into semi-arid areas of the Coolgardie and Avon Bioregions, and further north along the coast than the species in Assemblage-11a.

11c. Widespread temperate species of arid, semiarid and, often, mesic regions. They approach their northern limits at Shark Bay, where they converge with the coast and extend even further north because of coastal effects.

\section{Distributions Centred on Mesic Regions of the Temperate Zone}

Assemblage-12: Temperate, semi-arid to mesic species of sandy surfaces that sometimes mantle limestone. These are species of heath and scrubs, and are at their northern limits in coastal areas south of Shark Bay. The assemblage includes several specialists of deep sand surfaces that are centred on the strip from Geraldton $\left(29^{\circ} \mathrm{S} 114^{\circ} 30^{\prime} \mathrm{E}\right)$ to Shark Bay.

Assemblage-13: South-western heath specialists. This far north they need to be close to the coast. All of the plants are grasses or small heath plants; five of the 12 are restricted to coastal limestone surfaces. The others are found in sand- as well as limestoneheaths.

\section{Species Richness and Composition in Relation to Quadrat Attributes}

Several distinct step-wise structures dominate both the quadrat- and the species-dendrograms (Figures 2 and 3). Such structures would occur if the species-assemblages were responding to different gradients in the physical environment or differently to sub-sets of environmental gradients (McKenzie et al., 1989, 1991a). To test this hypothesis, the 13 species-assemblages were treated as independent data-sets and analysed separately.

When the 63 quadrats were classified in terms of the species belonging to each of the 13 assemblages, each assemblage's pattern of occurrence across the study area was summarised in the form of a dendrogram (e.g. Figures 4 and 6). As described in 'Methods', univariate data on aspects of the quadrats' physical environments were superimposed as histograms on each dendrogram, attribute-by-attribute to identify the physical attributes that most closely conformed to the patterns in each assemblage's species-composition across the study area. As a parallel analysis, the package GLIM was used to model the pattern of each assemblage's species richness across the study area in terms of the physical attributes of the quadrats (see Methods).

The results of these analyses are summarised in Table 5, and are explained below. Correlations between relevant environmental attributes are summarised in Table 6.

- Assemblage-1's compositional structure showed a significant fit to the gradient in floodplain situations (over-bank stream flow, 'gs-over', see Wyrwoll, Stoneman, Elliott and Sandercock, 2000) (Figure 4). Although non-ratio data such as 'gs-over' were not included in the GLM analysis, the GLM richness model confirmed the compositional result because low soil sodium (exNa) and high magnesium (exMg) characterise the regularly washed soils that occur in drainage lines and associated floodplains (Table 5). The attibutes 'exMg' and 'gs-over' were intercorrelated in our study area (Table 6).

Table 6 Environmental attributes that showed the best fit to the group structure of the dendrogram derived by classifying the quadrats according to similarities in their composition. 'Group Level' indicates the level at which the relevant quadrat dendrogram was cut (the number of partitions). Tight inter-correlations with attributes in the richness models are listed in the final column.

\begin{tabular}{llll}
\hline $\begin{array}{l}\text { Assemblage } \\
\text { (from Figure 3) }\end{array}$ & $\begin{array}{l}\text { Group } \\
\text { Level }\end{array}$ & Attribute & Inter-correlations: Kendall's Tau (p.) \\
\hline 1 & 4 & gs-over* & -0.33 with exMg $(0.0016)$ \\
2 & 3 & Pcld & 0.95 with Pwet $(<0.0001)$ \\
3 & 6 & Pwet, Pcld & -0.84 with Twar $(<0.0001),-0.87$ with Twar $(<0.0001)$ \\
4 & 3 & Pwar & Attribute is in model \\
5 & 6 & Psea & 0.81 with Pwet $(<0.0001)$ \\
6 & 4 & $\mathrm{~K}\left(\mathrm{HCO}_{3}\right)$ & 0.89 with exK $(<0.0001)$ \\
7 & 6 & Veg-type, Twet &,- 0.65 with Tann $(<0.0001)$ \\
8 & 4 & $\mathrm{Cl}$ & Attribute is in model \\
9 & 2 & Long & -0.58 with CaCO $(<0.0001)-0.53$ with Pwp $(<0.0001)$ \\
10 & 7 & Lat & Attribute is in model \\
11 & 8 & $\left.\mathrm{~K}(\mathrm{HCO})_{3}\right)$ & 0.89 with exK $(<0.0001)$ \\
12 & 5 & $\mathrm{~K}\left(\mathrm{HCO}_{3}\right)$, Pcld & -0.43 with Pann $(<0.0001), 0.71$ with Pann $(<0.0001)$ \\
13 & 2 & Stone & No model possible \\
\hline
\end{tabular}

\footnotetext{
* Ordinal data, not used in the GLM analysis.
} 
- Assemblage-2's compositional structure (Figure 12) conformed with a precipitation gradient (low 'Pwet') across fine-textured lowland soils (high in phosphorus, potassium and soil shear strength, and at low altitude) (Figure 5a). Temperature diurnal range (Tdi) provided separation of a compositional variant of this assemblage that occurs on suitable sites near the coast. The same set of attributes (Altitude, 'Pwet', Phosphorus, and 'Tdi') were significant in the fitted richness model (Table 5), although soil calcium carbonate was also significant.

- Assemblage-3's compositional structure conformed to 'temperature in the warmest quarter' ('Twar') and, within this, with annual precipitation (Figure 5b) and soil total nitrogen (Table 5). These attributes also gave the best GLM model of the assemblage's species richness.

- Assemblage-4's compositional structure conformed with 'warmest quarter precipitation' ('Pwar'). Within that, high 'temperature in the warmest quarter' ('Twar'), with either low soil potassium $\left(\mathrm{KHCO}_{3}\right)$ or low soil phosphorus $\left(\mathrm{PHCO}_{3}\right)$, isolated the inland sandy quadrats where the compositionally diverse examples of this assemblage occurred (Figure 5c). The same attributes provided the best richness model.

- Assemblage-5: These species were mostly nearubiquitous in the study area, although precipitation seasonality ('Psea') conformed to the assemblage's compositional structure (Figure 5d), with variants related to altitude ('Alt') and, at lower levels in the dendrogram, to soil calcium carbonate and soil magnesium. The tightest richness model used a similar set of attributes.

- Assemblage 6's compositional structure conformed with soil potassium ('exK') and 'vegtype'. Within that, low soil phosphorus (P), high precipitation seasonality and low soil shear strength distinguished the most compositionally diverse examples of this assemblage (group-5 from group-6) (Figure 5e). Groups-5 and 6 were also different in terms of soil cation exchange capacity ('CEC') and percentage clay. The richness model used the soil potassium and phosphorus, and the precipitation seasonality attributes (Table 5), although an alternative model used 'CEC' and 'precipitation in the warmest quarter' ('Pwar') instead of the seasonality attribute.

- Assemblage-7's compositional structure conformed with winter temperature ('Tcld'), with the most species-diverse examples at quadrats with cool winters, provided that they also had a Eucalyptus tree canopy (quadrats NA2, NE1-5 in Figure 6). If not, less than $10 \%$ of the assemblage's species were present. Hence the significance of 'Veg-type' (Table 5). The GLM model indicated that rich versions of this assemblage occurred in temperate, semi-arid sites, that were also low in soil phosphorus (Table 5).

- Assemblage-8's compositional structure conformed with altitude ('Alt'), soil salinity (e.g. ' $\mathrm{Cl}^{\prime}$ ) and phosphorus (' $\left.\mathrm{PHCO}_{3}{ }^{\prime}\right)$. The compositionally diverse sites were low in the landscape and had high phosphorus as well as either high soil chloride and/or high soil calcium carbonate levels; such sites were rich in magnesium ('exMg') (Figure 5f). Species richness was best predicted using soil chloride and calcium carbonate values in combination with temperature in the warmest quarter and precipitation in the warmest quarter. The temperature and precipitation attributes were an artifact because of the skewed occurrence of suitable environments in the study area; they were concentrated in northern near-coastal areas.

- Assemblage-9's compositional structure conformed with 'wettest period precipitation' ('Pwp') and longitude and, within these, with soil calcium carbonate (Figure $5 \mathrm{~g}$ ). Species richness was best predicted by GLM using the same precipitation and calcium attributes.

- Assemblage-10's compositional pattern conformed to Latitude, and within that, to soil phosphorus $\left(\mathrm{PHCO}_{3}\right)$ and 'temperature diurnal range' ('Tdi') (Figure 7). Rich assemblages occurred on the most northern quadrats, provided they were sands (i.e. soil phosphorus and potassium values were low), and had low 'annual temperature range' ('Tar') (Table 5). In the study area, low 'Tdi' and low 'Tar' are intercorrelated $\left(R^{2}=0.95\right.$, p. $\left.<0.0001\right)$ because they are coastal amelioration effects.

- Assemblage-11's gradient in composition conformed with high precipitation in the coldest quarter (Pcld: the wet winters of the temperate zone) and, within that, was influenced by distance from the coast ('cst-dist'), intercorrelated with longitude: $R^{2}=0.85, p .<0.0001$ ), soil exchangeable potassium ('exK') and/or soil exchangeable sodium ('exNa') (Figures 8 and $5 \mathrm{~h}$ ). Similar attributes were identified from the GLM analysis: the rich assemblages occurred on low potassium soils near the coast (low longitude) (Table 5).

- Assemblage-12's compositional structure conformed with 'precipitation in the coldest quarter' ('Pcld') (Figure 9). The rich assemblages occurred in quadrats with highest annual rainfall ('Pann') and lowest winter temperatures ('Tcld'), although soil sandiness (\% sand) and 
Figure 5 Physical attributes that separated the quadrat-groups defined by an assemblage's dendrogram. The relevent data matrices are provided in Figure 12. $\mathrm{N}=$ number of quadrats in each classification group (GRP), $" 1==M==3$ " indicates one standard deviation either side of the mean $(M)$, and * indicates that the mean and standard deviation points were too close to separate in the diagram. $\mathrm{H}=$ Kruskall-Wallis coefficient; $\mathrm{df}=$ degrees of freedom; $\mathrm{p}=$ probability).

\section{a. Assemblage-2, partitioned at the 3-, 5- and 8-group levels in the classification structure.}

Wet Quarter Precipitation (Pwet, $\mathrm{mm}$ ) (3 groups: $\mathrm{H}=32.3$, $\mathrm{df}=2, \mathrm{p}=<0.0001$ ).

\begin{tabular}{|c|c|c|c|}
\hline & & 120 & 180 \\
\hline $\begin{array}{l}\text { GRP } \\
1-3\end{array}$ & $\begin{array}{l}N \\
38\end{array}$ & $1=====\mathrm{=}=\mathrm{I}=\mathrm{M}=\mathrm{M}=\mathrm{=}=\mathrm{=}=\mathrm{3}$ & $-----\cdots--$ \\
\hline $4-7$ & 22 & & $1========\equiv===M======== \pm=3$ \\
\hline 8 & 3 & & 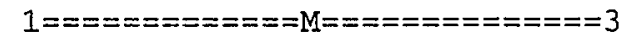 \\
\hline
\end{tabular}

Total Phosphorus (P, ppm) (5 groups: $\mathrm{H}=25.1 \mathrm{df}=4 \mathrm{p}=<0.0001)$.

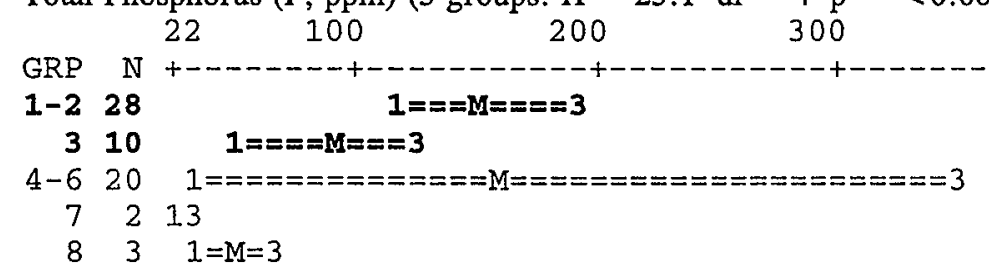

Temperature Diurnal Range (Tdi, $\left.{ }^{\circ} \mathrm{C}\right)(8$ groups: $\mathrm{H}=36.1$, $\mathrm{df}=7, \mathrm{p}=<0.0001$ ).



Altitude (m) (8 groups: $\mathrm{H}=20.7, \mathrm{df}=7, \mathrm{p}=0.004)$
1.0
88.3
175.5



Soil Potassium ( $\left(\mathrm{HCO}_{3}\right)$, ppm) (5 groups: $\mathrm{H}=40.4$, $\left.\mathrm{df}=4, \mathrm{p}=<0.0001\right)$

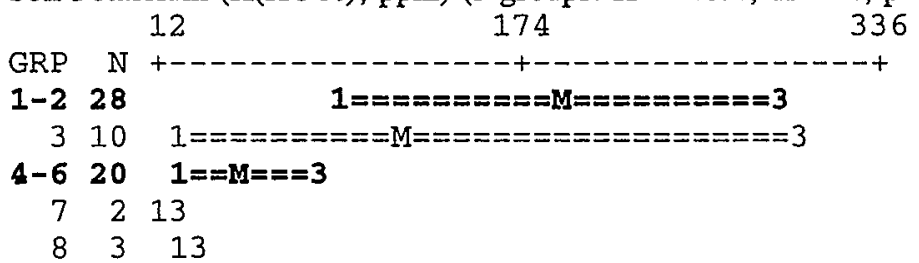

Soil Shear Strength (tx-shst, $\mathrm{kPa}$ ) (5 groups: $\mathrm{H}=32.5$, df $=4, \mathrm{p}=<0.0001$ )




Figure 5 (cont.)

\section{b. Assemblage-3, partitioned at the 6-group level.}

Warmest Quarter Mean Temperature (Twar, $\left.{ }^{\circ} \mathrm{C}\right)(6$ groups: $\mathrm{H}=42.0$, df $=5, \mathrm{p}=<0.0001)$.

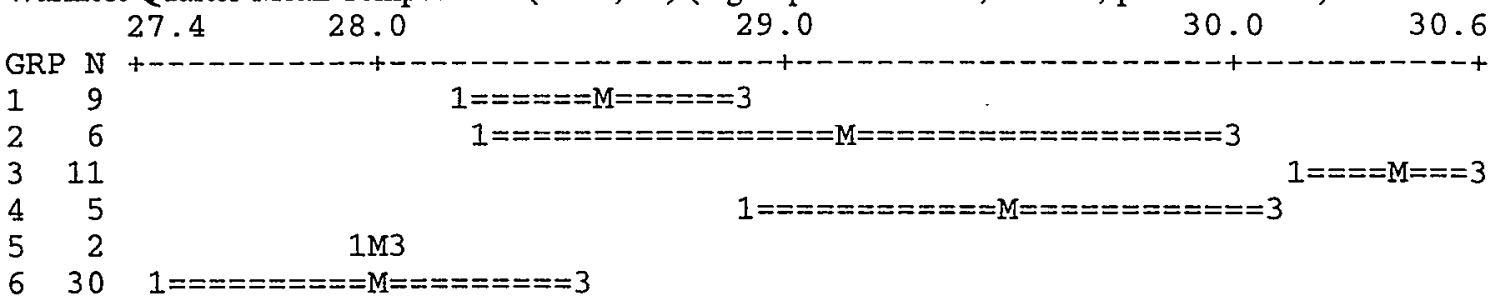

Annual Average Precipitation (Pann, $\mathrm{mm}$ ) (6 groups: $\mathrm{H}=33.8$, $\mathrm{df}=5, \mathrm{p}=<0.0001$ ).



\section{c. Assemblage-4, partitioned at the 3- and 7-group levels.}

Warmest Quarter Precipitation (Pwar, $\mathrm{mm}$ ) (3 groups: $\mathrm{H}=25.1$, $\mathrm{df}=2, \mathrm{p}=<0.0001$ ).

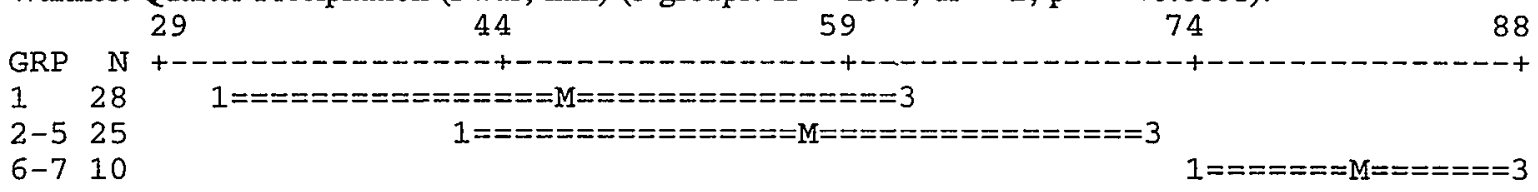

Warmest Quarter Temperature (Twar, $\left.{ }^{\circ} \mathrm{C}\right)(7$ groups: $\mathrm{H}=27.5$, df $=6, \mathrm{p}=0.0001$ ).

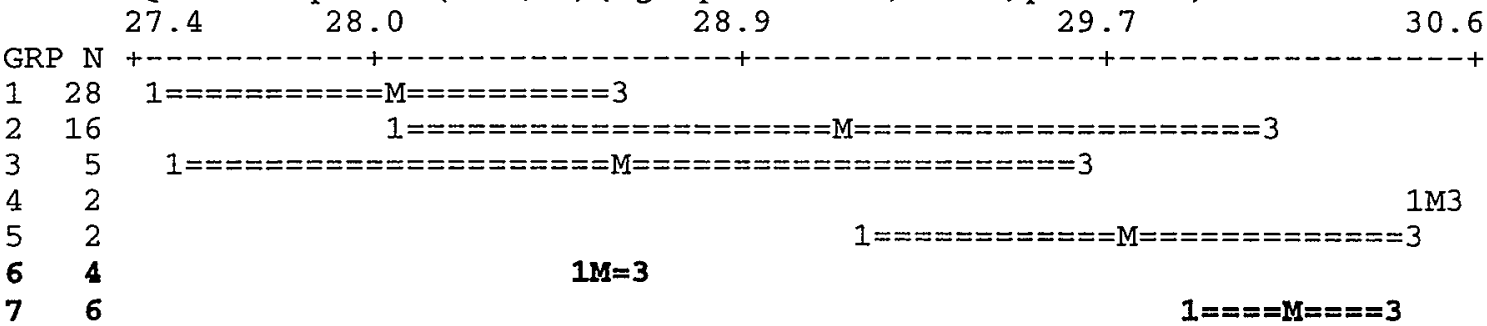

\section{d. Assemblage-5, partitioned at the 6- level.}

Precipitation Seasonality (Psea) (6 groups: $H=43.9$, df $=5, p=<0.0001$ ).

\begin{tabular}{|c|c|c|c|c|}
\hline & & 78 & 87 & \\
\hline GRP & $\mathbf{N}$ & +---- & $---+\cdots-----------+$ & - - \\
\hline $1-3$ & 16 & & $1======M=======3$ & \\
\hline $4-7$ & 36 & $1==========\mathrm{M}====== \pm===3$ & & \\
\hline 8 & 6 & & & $1==M==3$ \\
\hline 9 & 2 & & & \\
\hline 10 & 2 & & & $1 \mathrm{M} 3$ \\
\hline 11 & 1 & & & * \\
\hline
\end{tabular}

Altitude (m) (6 groups: $\mathrm{H}=26.3$, df $=5, \mathrm{p}=0.0001)$.

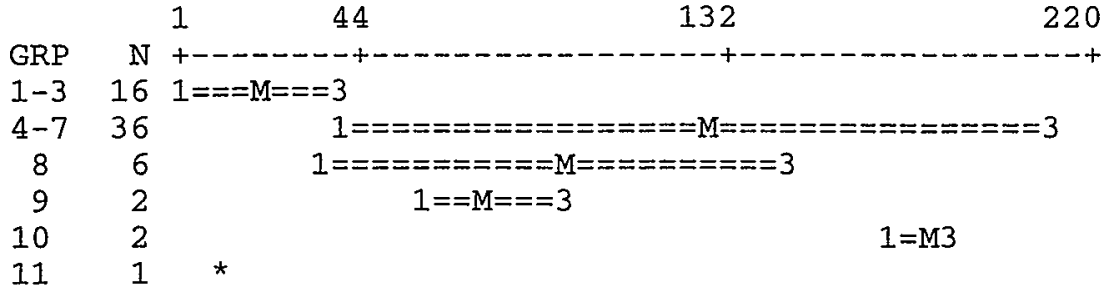


e. Assemblage-6, partitioned at the 4- and 9-group levels.

Exchangeable Potassium (exK) (4 groups: $\mathrm{H}=21.2$, df $=3, \mathrm{p}=0.0001$ ).



Vegetation Type (Veg-type) (4 groups: $\mathrm{H}=20.3$, df $=3, \mathrm{P}=0.0002$ ).



Precipitation Seasonality (Psea) (9 groups: $\mathrm{H}=15.2$, $\mathrm{df}=8, \mathrm{p}=0.055$ ).

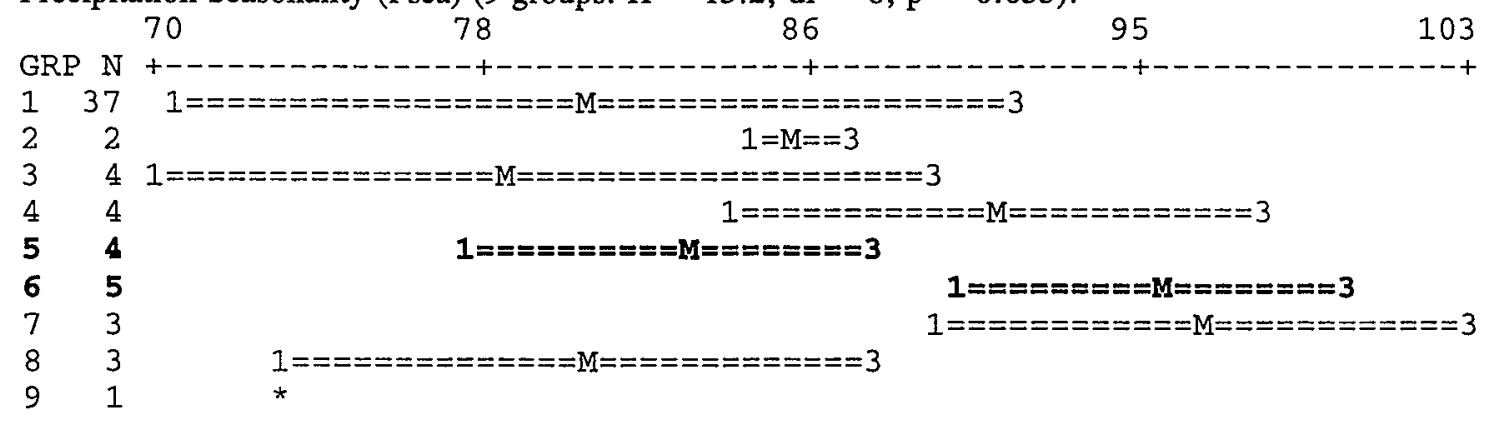

Total Phosphorus (P,ppm) (9 groups: $\mathrm{H}=26.6, \mathrm{df}=8, \mathrm{P}=0.0008)$.

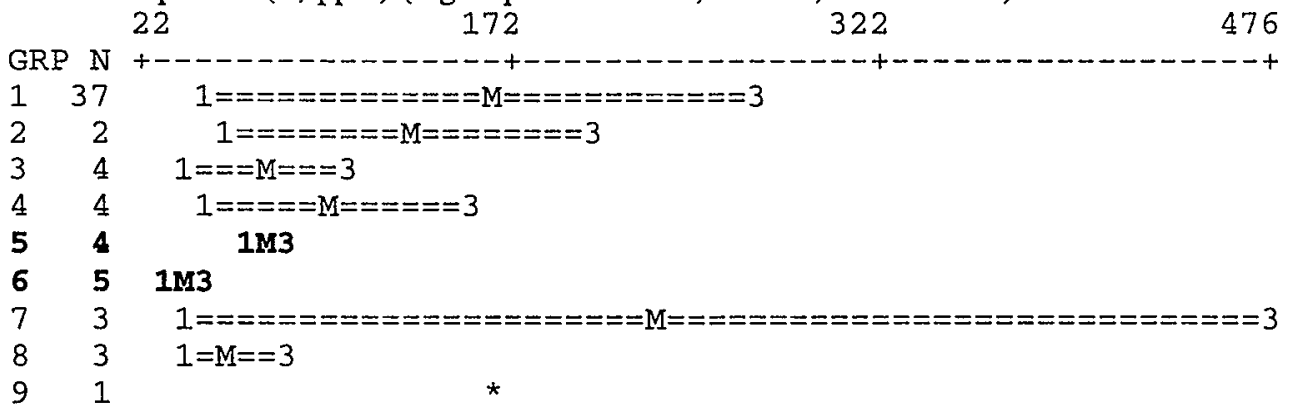

Soil Shear Strength (tx-shst, $\mathrm{kPa}$ ) (9 groups: $\mathrm{H}=16.5$, df $=8, \mathrm{p}=0.036)$.

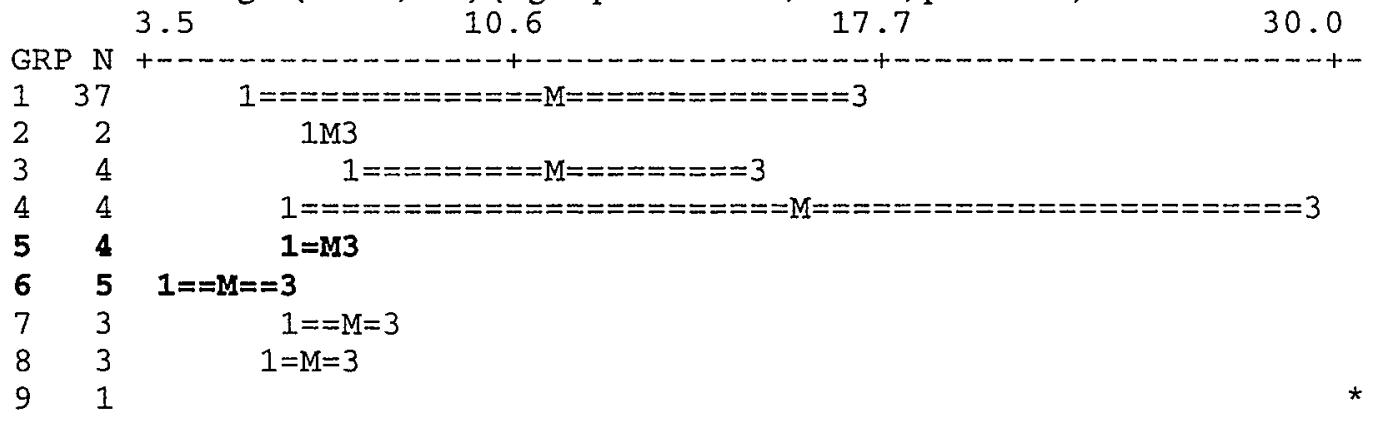


Figure 5 (cont.)

\section{f. Assemblage-8, partitioned at the 4- and 6-group levels.}

Chloride $(\mathrm{Cl}, \%)$ (4 groups: $\mathrm{H}=25.6$, $\mathrm{df}=3, \mathrm{P}=<0.0001$ ).

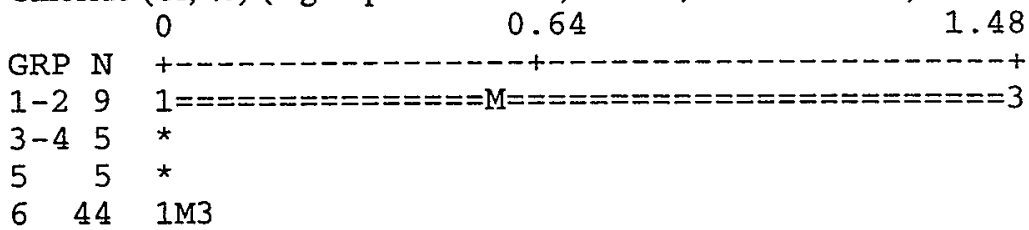

Soil Phosphorus $\left(\mathrm{P}\left(\mathrm{HCO}_{3}\right), \mathrm{ppm}\right)$ (4 groups: $\mathrm{H}=23.4$, df $=3, \mathrm{P}=<0.0001$ ).

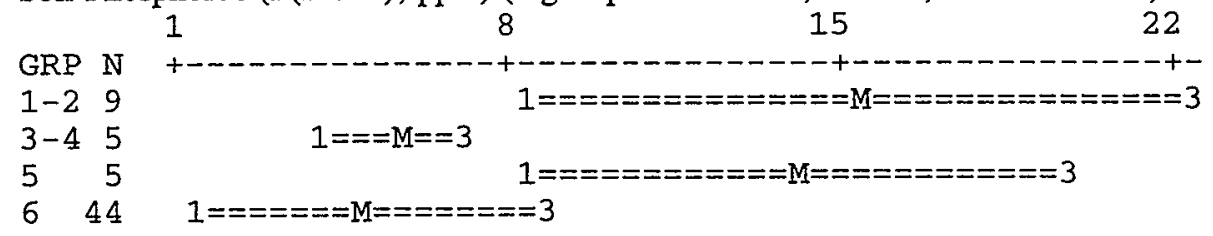

Altitude (m) (4 groups: $H=19.8$, df $=3, P=0.0002$ ).

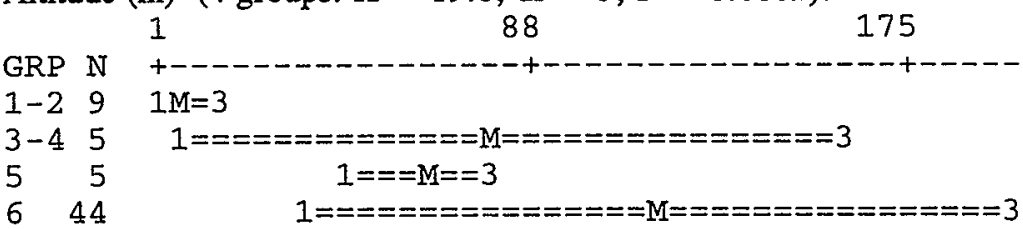

Electrical Conductivity ( $\mathrm{EC}, \mathrm{mS} / \mathrm{m})$ (6 groups: $\mathrm{H}=21.0, \mathrm{df}=5, \mathrm{P}=0.0008$ ).

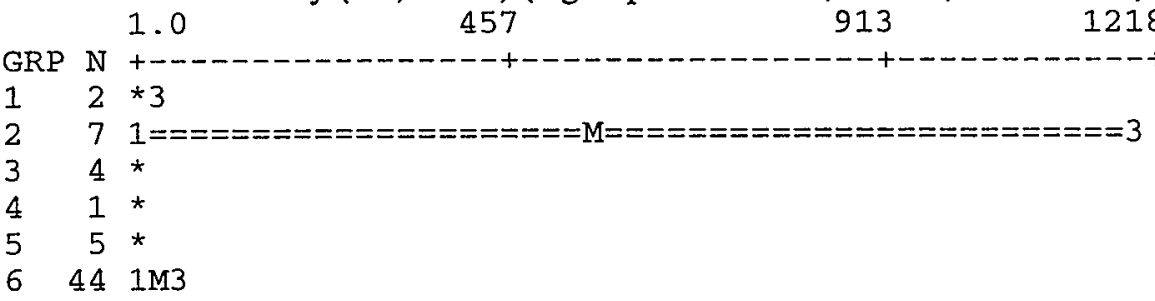

Soil Calcium Carbonate $\left(\mathrm{CaCO}_{3}, \%\right)(6$ groups: $\mathrm{H}=18.9$, df $=5, \mathrm{P}=0.002)$.

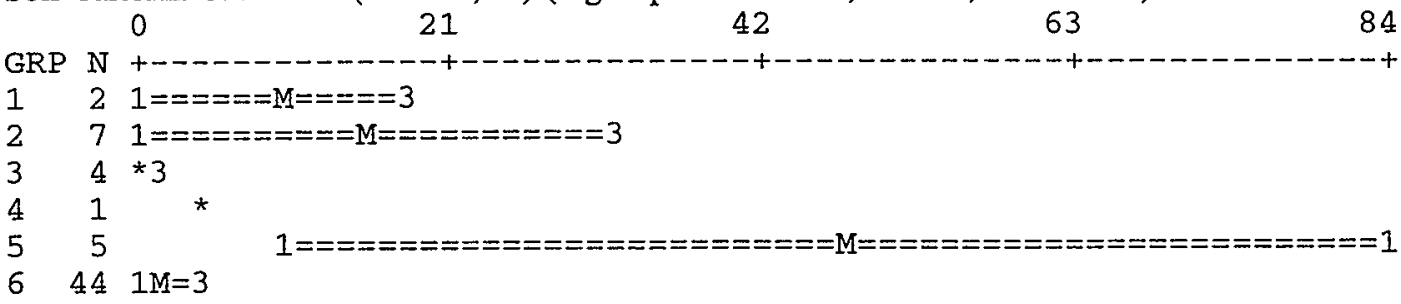

Exchangeable Magnesium (exMg, me\%) (6 groups: $\mathrm{H}=13.0$, df $=5, \mathrm{P}=0.024$ ).

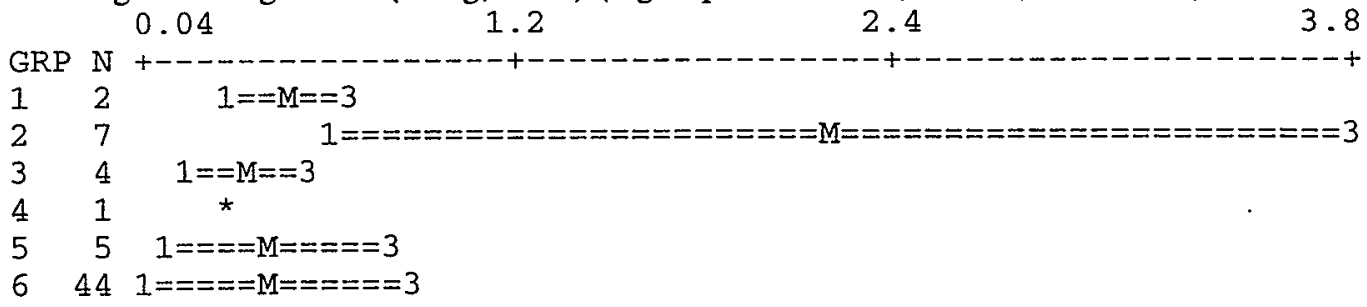




\section{g. Assemblage-9, partitioned at the 2- and 4-group levels.}

Wet Period Precipitation (PwP, mm) (2 groups: $H=8.3$, df $=1, \mathrm{p}=0.004$ ).

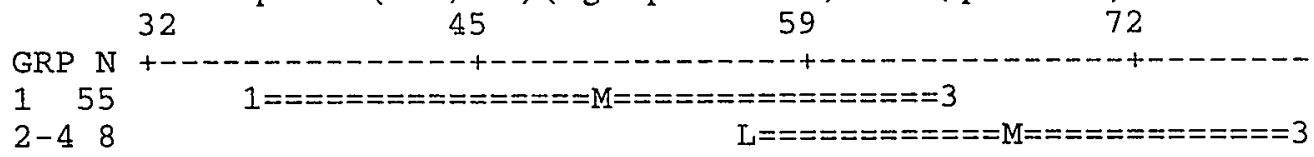

Soil Calcium Carbonate $\left(\mathrm{CaCO}_{3}, \%\right)$ (4 groups: $\mathrm{H}=10.7$, $\mathrm{df}=3, \mathrm{P}=0.01$ ).

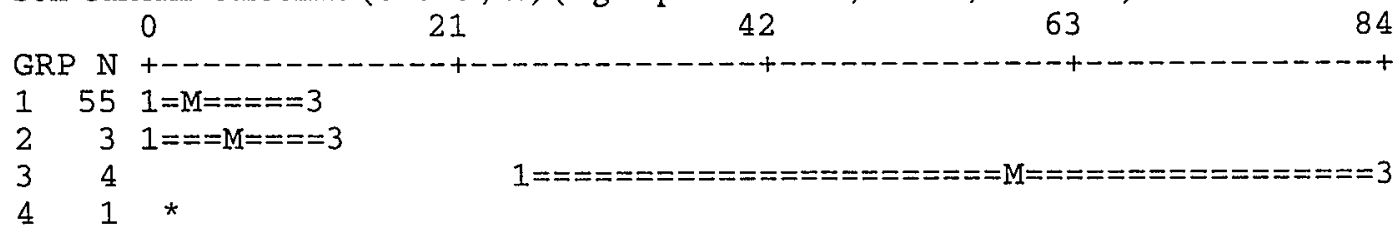

\section{h. Assemblage-11, partitioned at the 8- and 6-group levels.}

Cold Quarter Precipitation (Pcld, mm) (8 groups: $\mathrm{H}=37.9$, df $=7, \mathrm{p}=<0.0001$ ).

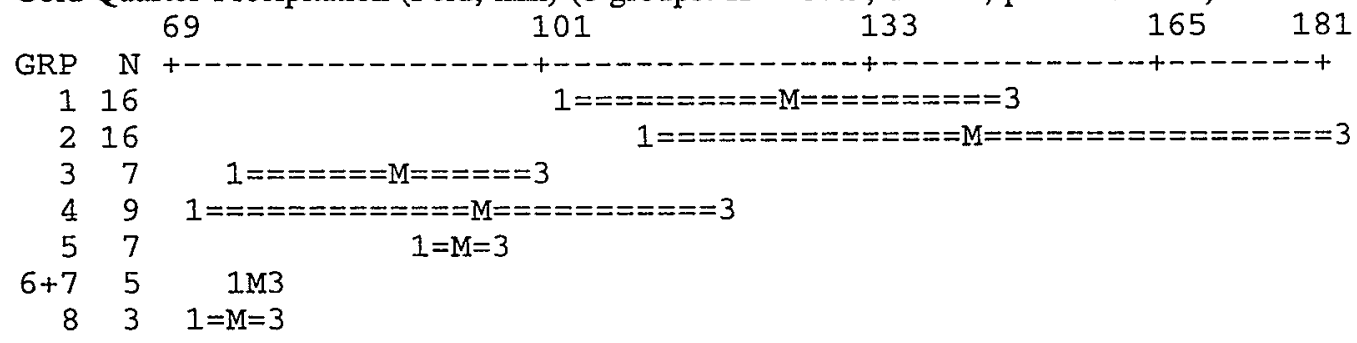

Coastal Distance (cst-dist, $\mathrm{km}$ ) (8 groups: $\mathrm{H}=38.1$, $\mathrm{df}=7, \mathrm{p}=<0.0001)$.

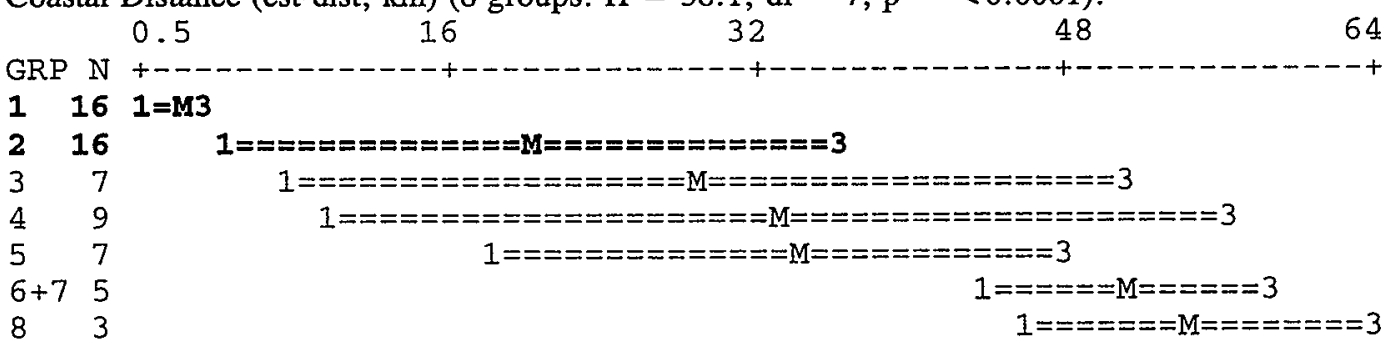

Exchangeable Potassium (exK, me \%) (8 groups: $H=40.2$, df: $7, p=<0.0001$ ).

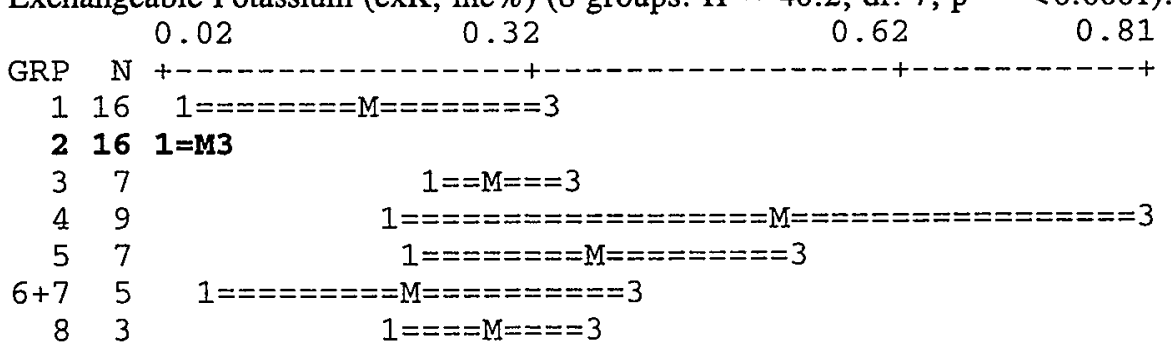

Exchangeable Sodium (exNa, me\%) (6 groups: $H=17.1$, df: $5, P .=0.004$ ).

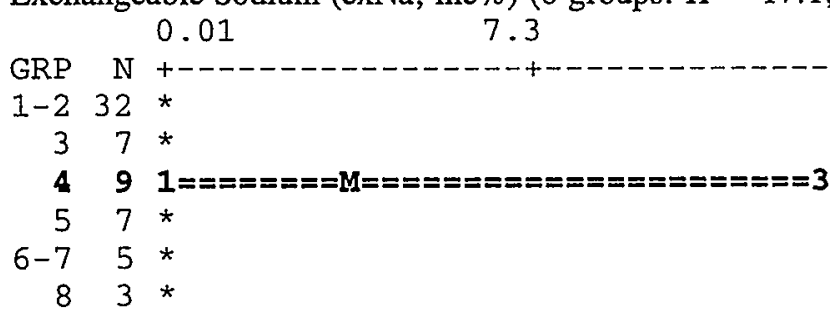


Table 7 Pearson correlation coefficents between the association matricies derived from each of the eight data-sets (the seven taxonomic sub-sets and the combined data.).

\begin{tabular}{llllllll} 
COMBINED & & & & & & & \\
BIRDS & 0.81 & & & & & & \\
CENTIPEDES & 0.35 & 0.17 & & & & & \\
MAMMALS & 0.50 & 0.33 & 0.11 & & & & \\
PLANTS & 0.79 & 0.48 & 0.15 & 0.40 & & & \\
REPTILES and FROGS & 0.75 & 0.50 & 0.30 & 0.36 & 0.52 & & \\
SCORPIONS & 0.46 & 0.38 & 0.18 & 0.22 & 0.27 & 0.32 & \\
SPIDERS & 0.71 & 0.42 & 0.30 & 0.34 & 0.45 & 0.53 & 0.30 \\
\hline
\end{tabular}

'cation exchange capacity' ('CEC') modified the relationship (Table 5). 'Pann' and 'Pcld' are tightly intercorrelated $\left(R^{2}=0.71, \mathrm{p} .<0.0001\right)$.

- Assemblage-13: comprises species that were only recorded in the study area at quadrats ZU1 and ZU2. These sites had the highest precipitation in the coldest quarter ('Pcld') of any quadrat sampled in the study area. They were also different from other southern sites by being on a coastal limestone ridge (hence the significance of 'Stone'), that was thinly mantled in sand (Figure 10). This assemblage was too localised for the richness model to converge.

\section{Influence of the Taxonomic Sub-sets on the Biodiversity Model}

The results of the sub-set comparison are presented in Table 7 and Figure 11. Figure 11 maps the position of each of the matrices in a three- dimensional ordination space defined in terms of the differences between their biodiversity patterns. Three features were noted:

1. The sub-sets were positioned all around the community matrix, so it would shift in 'biodiversity space' if any sub-set was eliminated.

2. The 'minimum spanning tree' linkages showed that the sub-sets were closer to the combined (community) matrix than to one another. We concluded that no sub-set provided a surrogate for another sub-set.

3. When 1000 randomly-generated matrices were added to the analyses, the cloud of random points was an average of 2.01 "nearest neighbour distance" units away from the community model, with $99 \%$ of these points between 1.92 and 2.13 units away. In comparison, the cluster of taxonomic sub-sets



Figure 6 Attribute values for 'temperature in the coldest quarter' (Tcld) and 'vegetation type' (Veg-type) superimposed as histograms on the dendrogram structure derived from the classification of the 63 quadrats in terms of species belonging to assemblage-7. Quadrat codes are printed vertically. The relevant re-ordered data matrix is provided in Figure 12. 


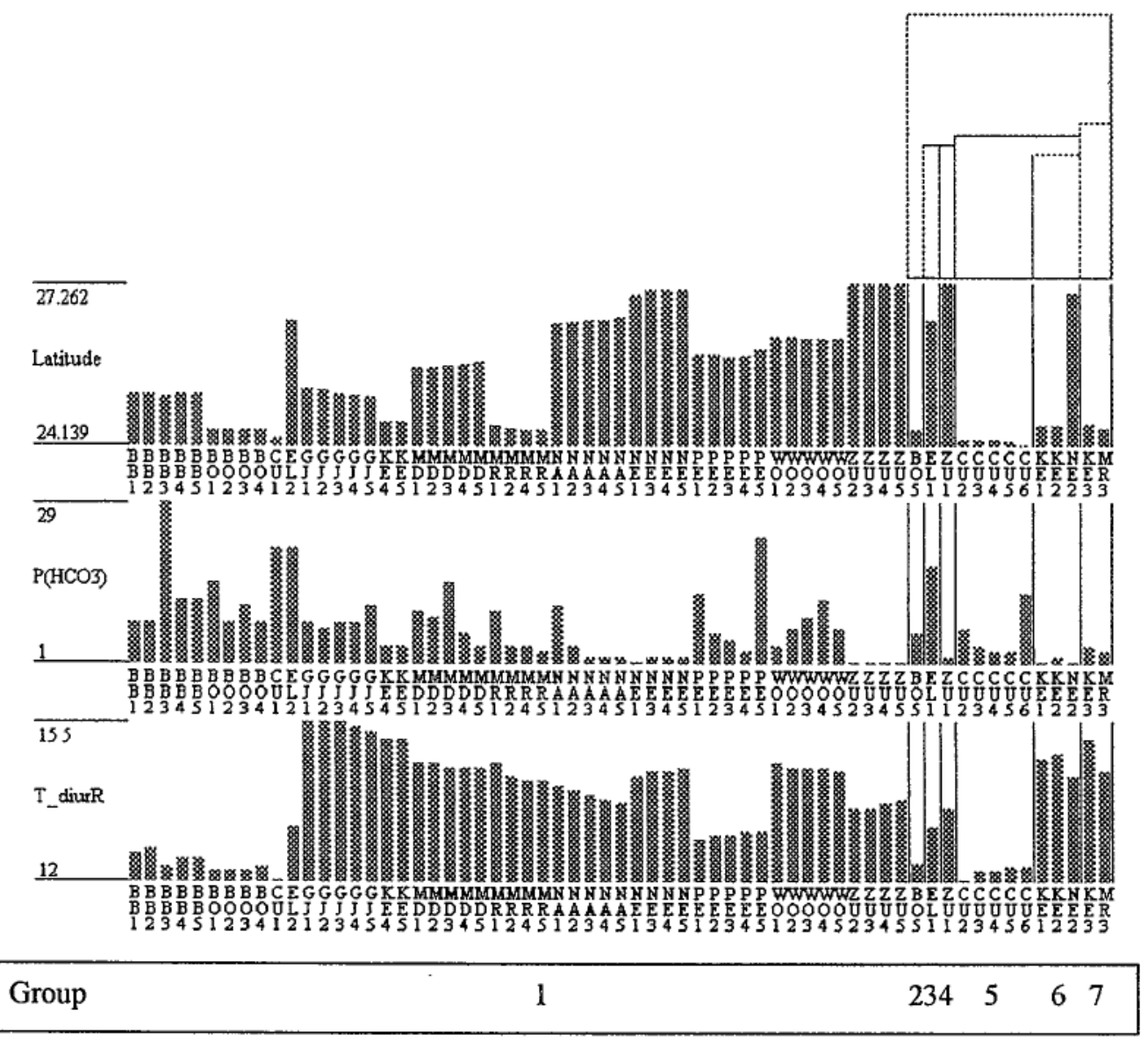

Figure 7 Attribute values for 'latitude', 'soil phosphorus' $\mathrm{P}\left(\mathrm{HCO}_{3}\right)$ and 'temperature diurnal range' (Tdi) superimposed as histograms on the dendrogram structure derived from the classification of the 63 quadrats in terms of species belonging to assemblage-10. Quadrat codes are printed vertically. The relevant re-ordered data matrix is provided in Figure 12.

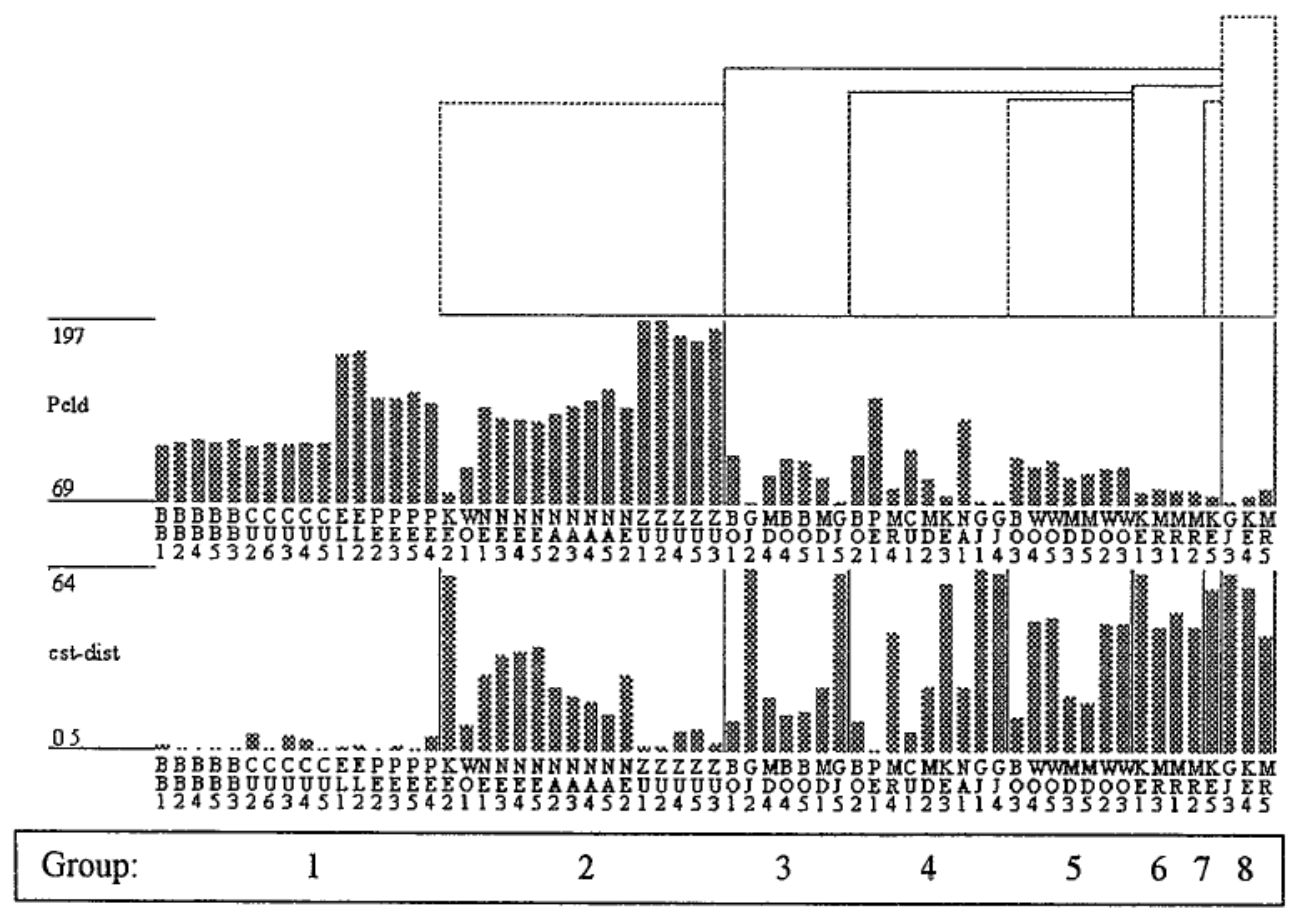

Figure 8 Attribute values for 'precipitation in the coldest quarter' (Pcld) and 'distance to coast' (cst-dist) superimposed as histograms on the dendrogram structure derived from the classification of the 63 quadrats in terms of species belonging to assemblage-11. Quadrat codes are printed vertically. The relevant re-ordered data matrix is provided in Figure 12. 


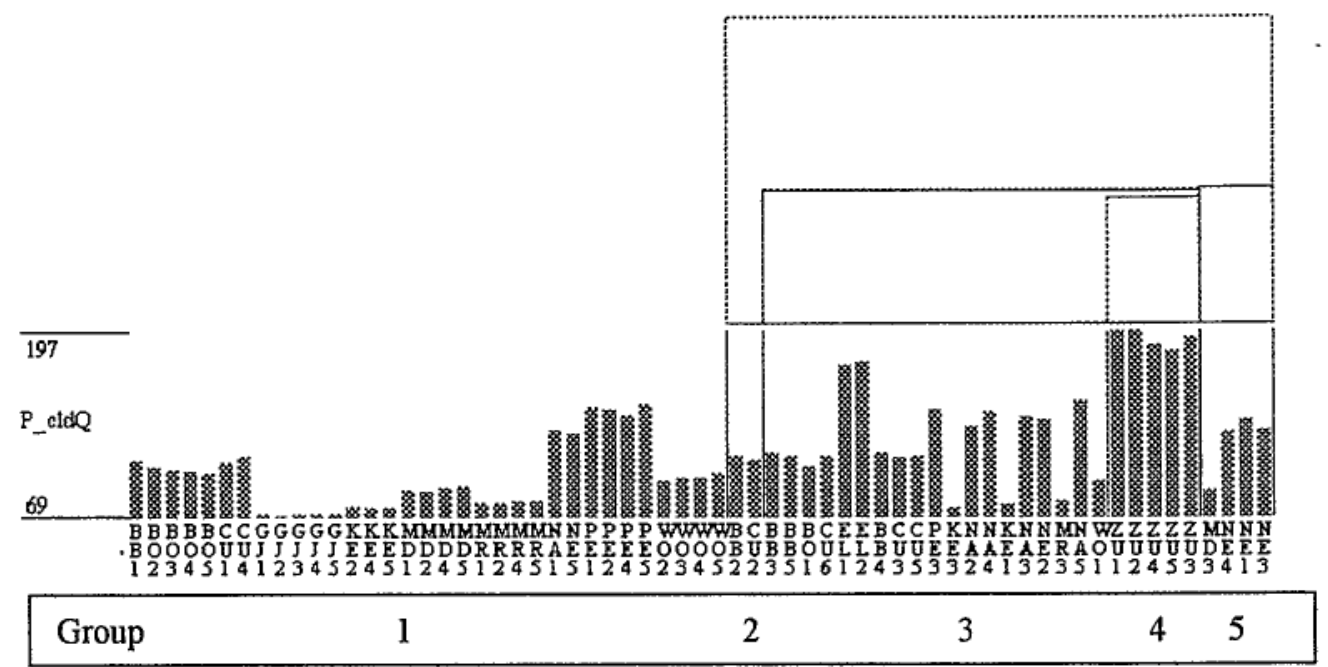

Figure 9 Attribute values for 'precipitation in the coldest quarter' (Pcld) superimposed as an histogram on the dendrogram structure derived from the classification of the 63 quadrats in terms of species belonging to assemblage-12. Quadrat codes are printed vertically. The relevant re-ordered data matrix is provided in Figure 12.

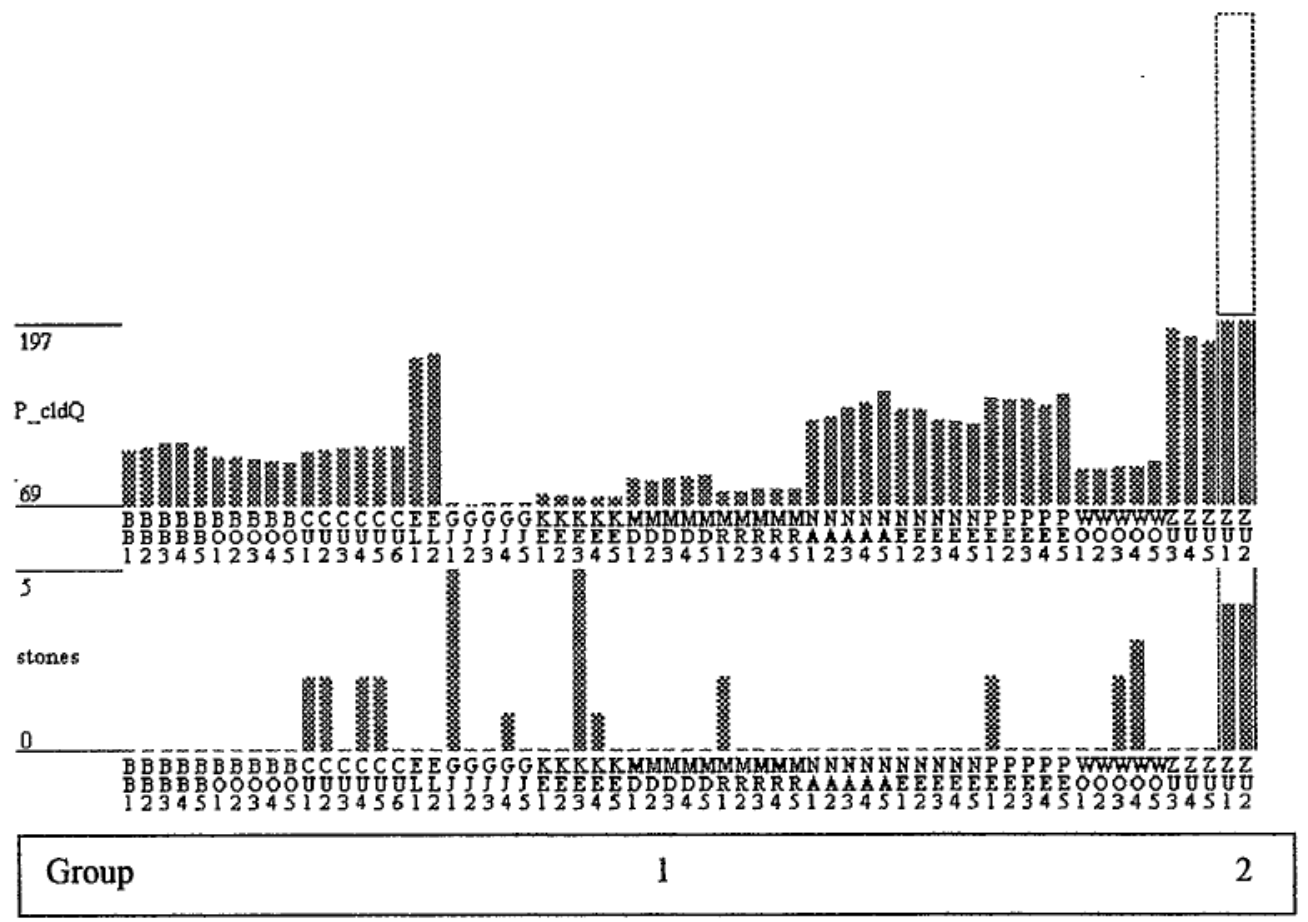

Figure 10 Attribute values for 'precipitation in the coldest quarter' (Pcld) and 'soil rockiness' (stones) superimposed as histograms on the dendrogram structure derived from the classification of the 63 quadrats in terms of species belonging to assemblage-13. Quadrat codes are printed vertically. The relevant re-ordered data matrix is provided in Figure 12.

had a radius that was $80 \%$ of this distance $(1.6$ units). Thus, the seven sub-sets were all wellseparated from the community model, indicating that they had very different patterns of occurrence; none was its surrogate.

\section{DISCUSSION}

Species co-occurrence patterns in most of the southern Carnarvon Basin still approximate preEuropean patterns because indigenous vegetations have not been cleared, known extinctions have been virtually confined to the relatively narrow mammalian component of the biota, and only a few of the introduced weeds are pervasive and/or allelopathic (e.g. Cenchrus ciliaris). Nevertheless, the dense populations of exotic herbivores have reduced the perennial vegetative cover and productivity of most surface-types, and changed the 


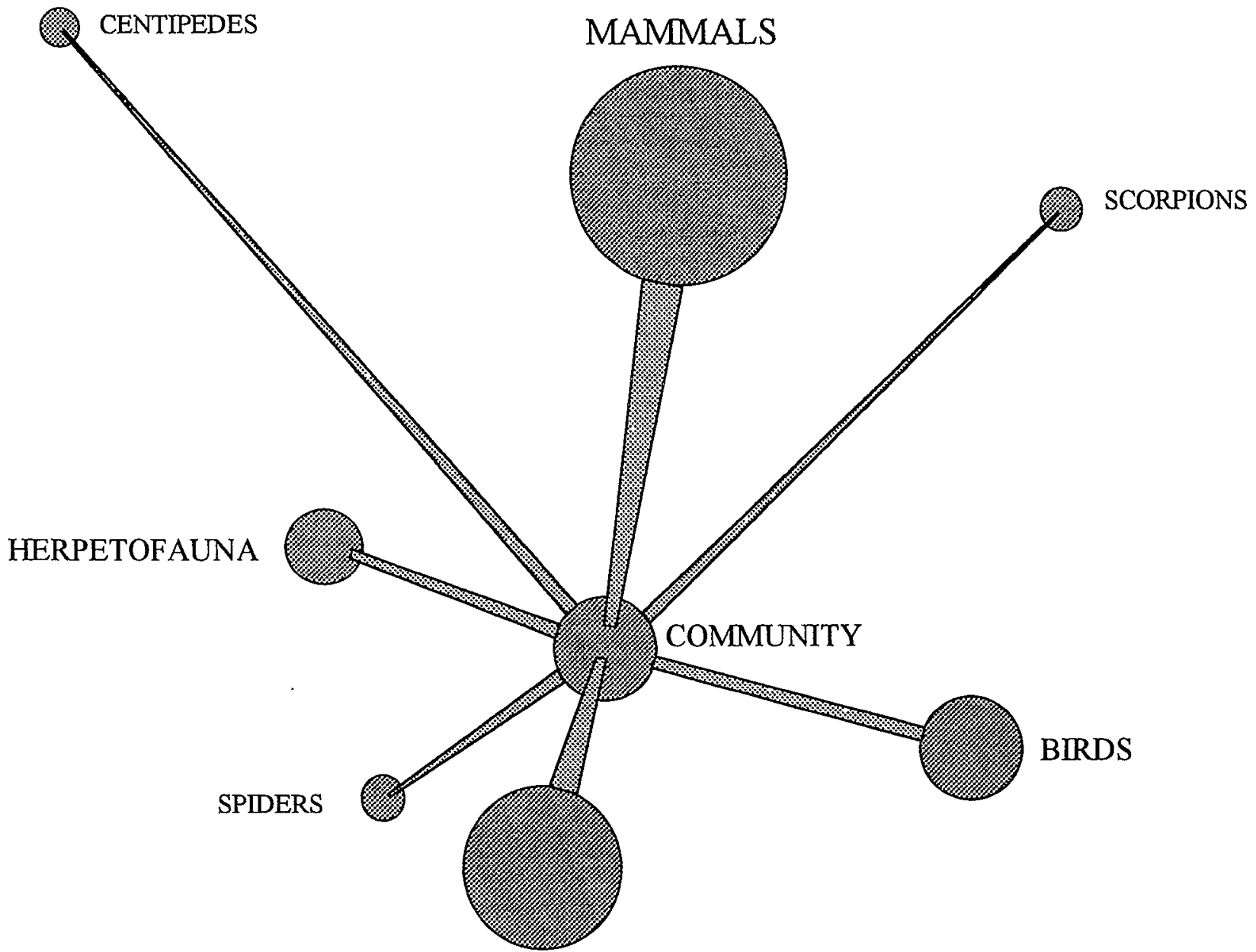

PLANTS

Figure 11 Comparison of the biodiversity patterns derived from the seven sub-sets sampled, and from the total dataset. A matrix of correlation coefficients was compiled from a pairwise comparison of the relevant quadrat similarity matrices. Results are displayed in three-dimensions using Semi-strong Hybrid Scaling (Belbin, 1991, stress $=0.13$ ). Minimum Spanning Tree linkages (Belbin, 1995) are superimposed to indicate nearest neighbours in biodiversity space.

relative abundance of their plant species (Beard, 1976; Friedel and James, 1995; Landsberg et al., 1997; Wyrwoll, Stoneman, Elliott and Sandercock, 2000).

When we compared the species richness of quadrats according to surface-type, the saline surfaces were the poorest regardless of their condition, and red sand surfaces were the richest. Red sands dominate Australia's arid zone, and their richness can be explained by an area effect (cf. Rosenzweig, 1992) in conjunction with their unsuitability for pastoral-use (Payne et al., 1987). Yet our comparison also indicated that pastoral usage has not had a significant effect on the overall richness of indigenous species on the quadrats; even the most degraded quadrats had similar species richness to quadrats with little overt usage. While this result supports the view that preEuropean co-occurrence patterns in species composition can be derived from our data-set, the similarity may be partly an artifact of our sampling regime. We positioned the quadrats in the least disturbed examples of each habitat-type that we could find because we aimed to provide the first quantitative biodiversity benchmark against which future changes in the compositional complexity of the region's indigenous ecosystems can be measured.

Several distinct stepwise structures dominated both the quadrat and the species classification dendrograms (Figures 2 and 3 ). In the context of our study, this would occur if the component species were responding to different environmental gradients and/or to the same gradients differently. On the reasoning that species which usually cooccur are more likely to be responding to the same environmental gradient/s than are species with different patterns of co-occurrence (see McKenzie et al., 1989, pp. 255-6), we sought to untangle the biogeographical processes by treating the 13 species assemblages derived from the overall analysis as independent data-sets, and analysing them 
Figure 12 Data matrices for each of the 13 assemblages defined from the species classification analysis (Figure 3). Quadrat codes are printed vertically. Quadrats have been re-ordered and clustered according to their species similarities within the relevant assemblage. $\mathrm{A}=$ frog, $\mathrm{B}=$ bird, $\mathrm{C}=$ centipede, $\mathrm{PL}=$ plant, $\mathrm{SC}=$ scorpion, $\mathrm{SP}=$ spider and $\mathrm{R}=$ lizard.

ASSEMBLAGE NUMBER

Assemblage-1

B Australian Magpie

PI Calandrinia ptychosperma

SP (Salticicdae) U11 sp1

B Yellow-rumped Thornbill

A Pseudophryme guentheri

PI Lotus australis

PL Sisymbrium erysimoides

PL Gymnema granitica MS

PL Indigofera colutea

$\mathrm{R}$ Amphibolurus longirostris

PL Emex australis

A Litoria rubella

PL Eucalyptus victrix

B Red-backed Kingfisher

B Little Corella

$R$ Ctenotus severus

A Uperoleia russel1i
B Black-faced Cuckoo-shrike

B Diamond Dove

PL Calandrinia sp. (GJK\&NG1495)

$B$ Mulga Parrot

PL Eremophila subfloccosa

PL Abutilon otocarpum

PL Phyllanthus maderaspatensis

PL Asphodelus fistulosus

PL Chenopodium cristatum

PL Paspalidium basicladum

PL Ptilotus aervoides

PL Cassia helmsii

SP Opopaea sp4

$B$ Southern Whiteface

$\mathrm{R}$ Rhynchoedura ornata

PL Ptilotus villosiflorus

A Neobatrachus wilsmorei

PI Salsola kalj

PL Acacia victoriae

PL Tragus australianus

PL Corchorus walcottii

PL Stenopetalum pedicellare

PL Triraphis mollis

PL Bulbostylis barbata

SP Argiope protensa

C Asanada spp

$B$ Crimson Chat

PL Dysphania rhadinostachya

$B$ Little Button-quail

SP Neosparassus sp8

PL Abutilon oxycarpum

PI Eriachne dominii

PL Sida kingii

PL Chthonocephalus spathulatus

PL Parietaria debilis

$B$ White-backed Swallow

SP Jotus spl

PL Rhodanthe charsleyae

SP Forsterina sp3

B Hooded Robin

PL Cuscuta epithymum

PL Gnephosis arachnoidea

PL Lepidium rotundum

PL Zygophylium ovatum

PL Podolepis capillaris
CLASSIFICATION GROUP NUMBER (GRP in Fig. 5; Group in Figs 4, 6-10)

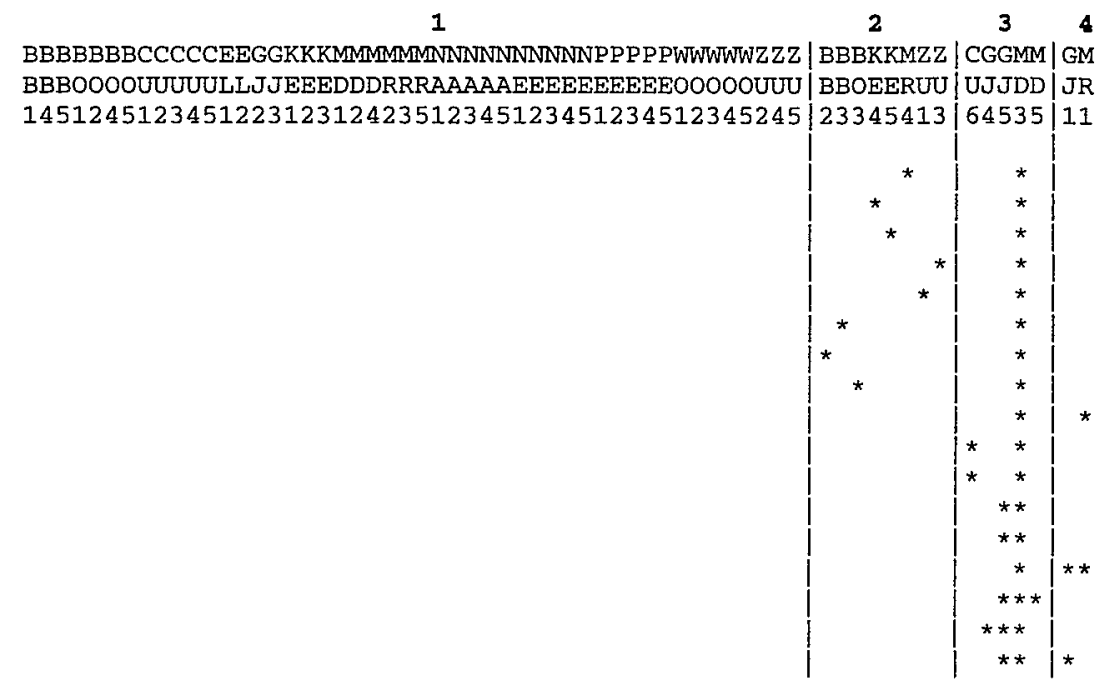

4 BOOOBU |OOEEJEJJJJDDDDDRAOOOOO UEEAEERRRR | BBUUAUBEEUE UUE LELUAEE | UU | AEU

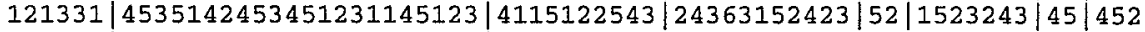

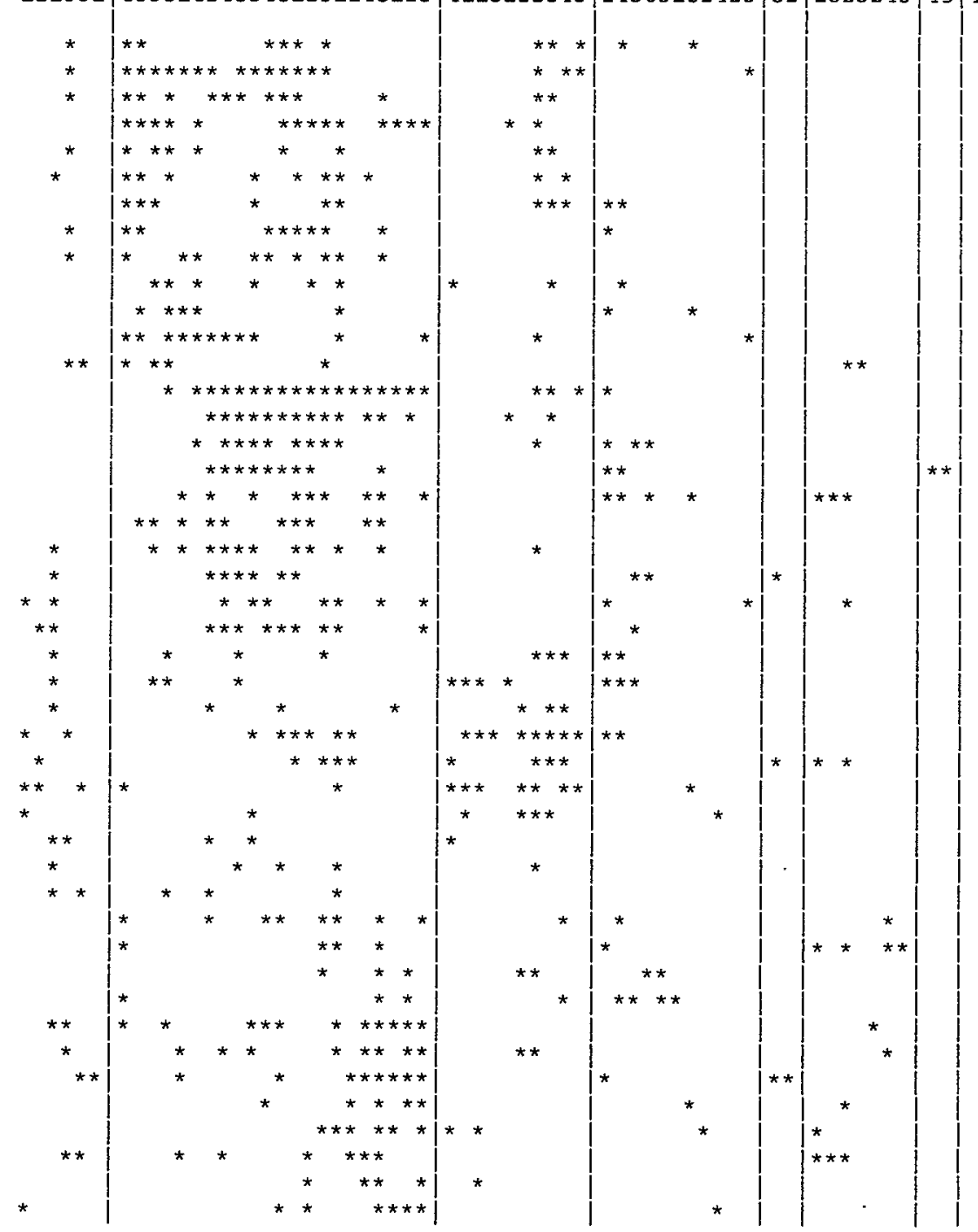


PL Tetragonia cristata

R Egernia depressa

PL Schoenia cassiniana

PL Acacia linophylla

PI Spartothamnella teucrififora

PI Myriocephalus guerinae

SP Grymeus sp4

SP Paraplatoides? sp1

SP Oonopidae Genus1 sp1

PL Tribulus forrestii

PL Convolvulus erubescens

PL Heliotropium undulatum

PL Hypochaeris glabra

PL Lotus cruentus

PL Rhodanthe psammophila

$\mathrm{R}$ Diplodactylus conspicillatus

SP Lycosa sp9

PL Cephaliptexum arummondii

SP Lycosa sp16

PL Calotis multicaulis

PL Senecio glossanthus

SC Urodacus hoplurus

PL Calotis hispidula

PL Solanum cleistogamum

PL Glycine canescens

PL Lepidium linifolium

PL Swainsona pterostylis

M Sminthopsis crassicaudata

PL Sclerolaena eurotioides

SP (Lycosidae) Genus1 sp2

SP Opisthoncus sp1

PL Atriplex vesicaria

PL Maireana tomentosa

SC Isometroides angusticaudis

$R$ Ctenophorus nuchalis

PL Sclerolaena densiflora

PL Pogonolepis muelleriana

PL Rhagodia drummondi

PL Boerhavia gardneri

PL Hakea preissii

$\mathrm{R}$ Diplodactylus klugei

SP Lycosa sp3

$M$ Antechinomys laniger

PL Maireana carnosa

PL Trianthema triquetra

PI Rhodanthe citrina

PI Eremophila crenulata MS

PL Tribulus cistoides

PI Sclerolaena recurvicuspis

PL Brachyscome ciliaris

PL Portulaca oleracea

PL Amaranthus mitchellii

PL Commicarpus australis

PL Enteropogon acicularis

PL Eremophila latrobei

PL Atriplex lindleyi inflata

PL Eremophila clarkei

PL Eremophila leucophylla

PL Ptilotus grandiflorus

PL Acacia grasbyi

PL Sarcostemma viminale

PI Cassia sp.

PI Thysanotus speckii

PL Atriplex semilunaris

PL Sisymbrium irio

C Cormocephalus strigosus

PL Leichardtia australis

PL Rhagodia eremaea

PL Senecio gregorii

A Neobatrachus sutor

PI Lobelia winfridae

SP Hypoblemum sp1

SP Lampona cylindrata

B Rainbow Bee-eater

SP (Desidae) Genus2 sp1

SP Grymeus sp2

PL Adriana tomentosa

PL Trichodesma zeylanicum

PL Lawrencia densiflora

PL Wahlenbergia tumidifructa

SP Gamasomorpha sp2
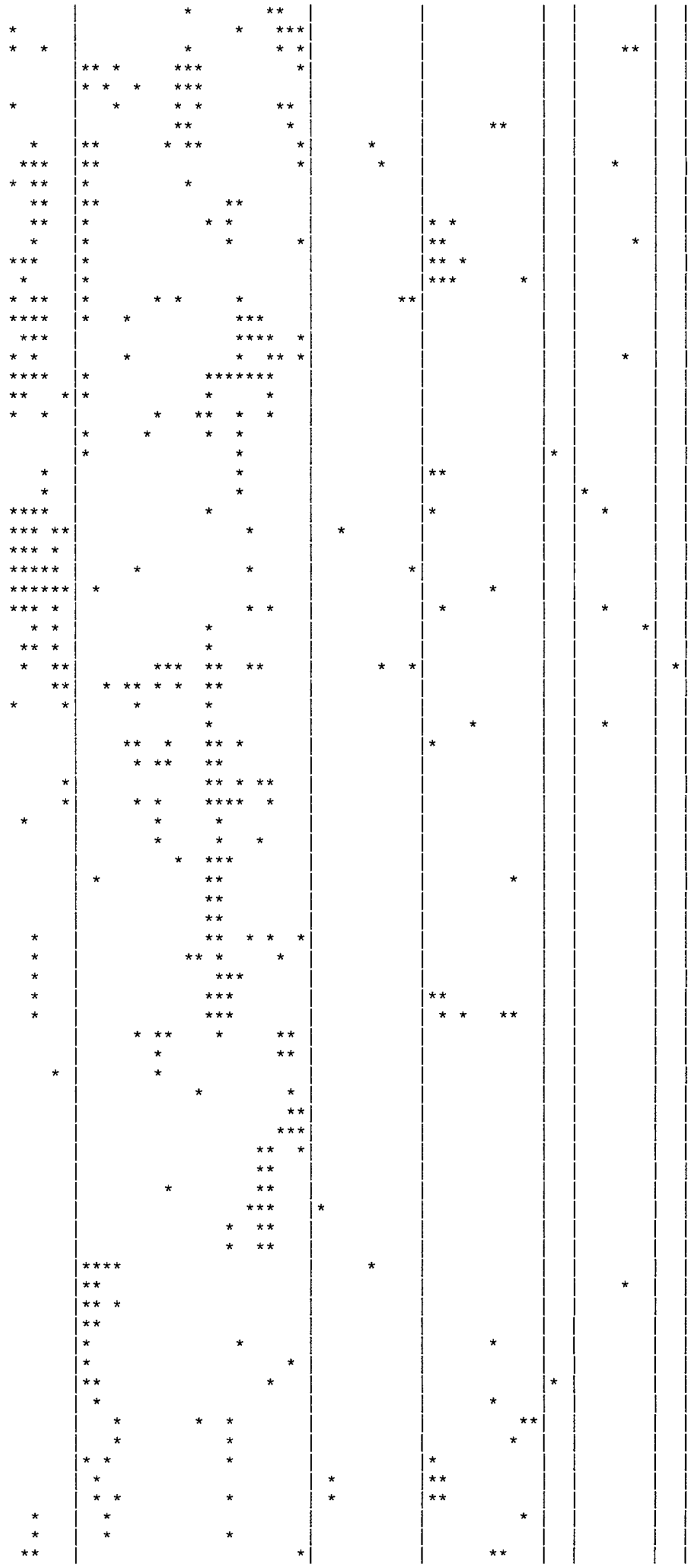
Figure 12 (cont.)

SP Neosparassus sp9

SP (Stiphidiidae) Genusl sp1

PL Dactyloctenium radulans

PL Eragrostis basedowi

PI Tribulus terrestris

$\mathrm{R}$ Tiliqua occipitalis

PL Calandrinia eremaea

PL Rhodanthe chlorocephala

PL Maireana trichoptera

PI. Angianthus tomentosus

PI Lawrencia spicata

R Ctenotus mimetes

PI Maireana georgei

PI Zygophyllum kochii

SP Maratus vespertilio

PI Acanthocarpus verticillatus

\section{Assemblage-3}

B Chestnut-breasted Quailthrush

$\mathrm{R}$ Lerista muelleri(d)

PL Enneapogon caerulescens

SP Miurga sp3

PL Acacia xiphophylla

PL Haloragis trigonocarpa

R Ctenotus uber

PL Sauropus crassifolius

SP Cytaea sp1

PL Sida corrugata

PL Stenopetalum sphaerocarpum

M Sminthopsis macroura

SP Lycosa sp18

PL Ptilotus exaltatus

B Slaty-backed Thornbil1

PL Goodenia tenuiloba

B Iittle Woodswallow

M Sminthopsis longicaudata

PL Cassia sturtii

PL Ptilotus polakii

PL Hibiscus burtonii

PI Indigofera monophylla

PL Streptoglossa liatroides

$B$ Grey-crowned Babbler

PL Ptilotus helipteroides

PL Tribulus astrocarpus

B Cockatiel

PL Acacia aneura

C Ethmostigmus pachysoma

$B$ Torresian Crow

PL Tripogon loliiformis

PL Eriachne pulchella

PL Goodenia havilandii

SP Pediana tenuis

SP Lycosa sp19

PL Eriachne helmsi

PL Yakirra australiensis

PL Cleome viscosa

PL Lepidium oxytrichum

PL Eriachne aristidea

$R$ Lerista gascoynensis

R Lerista muelleri(a)

A Cyclorana maini

A Limnodymastes spenceri

SP (Stiphidiidae) Genus3 spl

PL Panicum effusum

PL Sida aff. intricata

A Neobatrachus fulvus

A Neobatrachus aquilonius

PL Marsdenia viridiflora

\section{Assemblage-4}

B Black Honeyeater

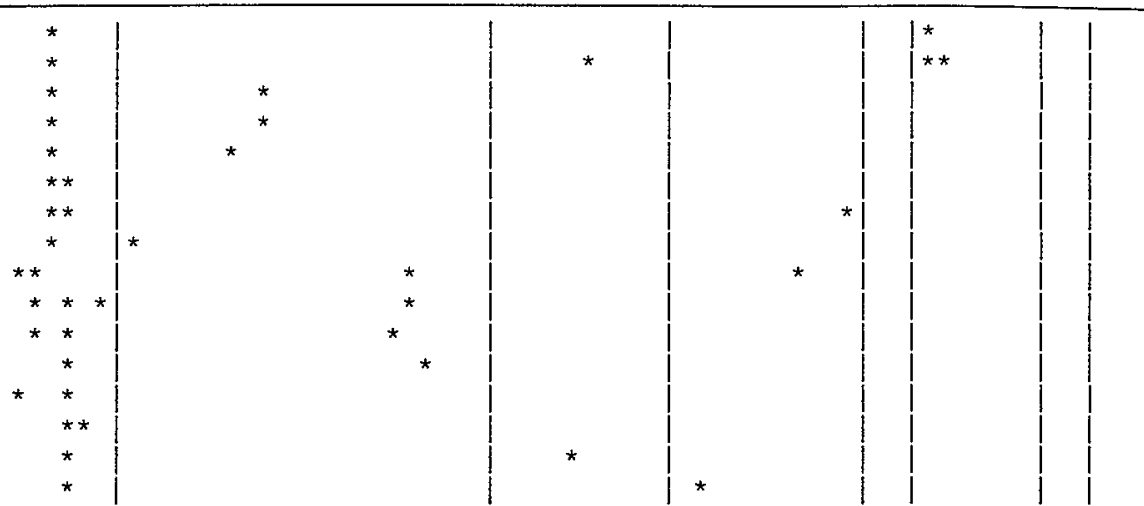

$\begin{array}{llllll}1 & 2 & 3 & 4 & 5 & 6\end{array}$

BCBWWBCWM / BMNWKM | GGGGGMMKKKM / KMMMW / NP | BBBBBBCCCCEEMNNNNNNNNNPPPPZZZZZ BUOOOBUOD / BDAOER IJJJJJRREEER IEDRD | EE |BBOOOOUUUULLDAAAAEEEEEEEEUUUUU $162543135|511224| 12354253451|14331| 53 \mid 241345234512223451234124512345$

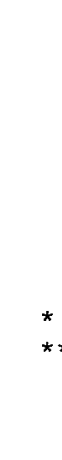


SP (Salticidae) U17 sp1

PI Acacia murrayana

PI Brachychiton gregorii

M Dasykaluta rosamondiae

B Rufous-crowned Emu-wren

$\mathrm{R}$ Ctenotus saxatilis

$\mathrm{R}$ Diporiphora winneckei

$\mathrm{R}$ Notoscincus ornatus ornatus

PL Plectrachne schinzii

SP Holoplatys planissima gp

B Bourke's Parrot

PL Waitzia acuminata

PL Hibiscus coatesii

PI Pityrodia paniculata

PI Psammagrostis wiseana

PL Indigofera occidentalis MS

PI Grevillea stenobotrya

PL Corynotheca pungens

PL Tephrosia gardneri (GJK\&NG1074)

$\mathrm{R}$ Ctenophorus femoral is

PL Verticordia forrestii

R Diplodactylus stenodactylus

PL Eriachne avenacea

PL Maireana planifolia

PL Thyridolepis mitchelliana

PL Acacia anastema

SP (Stiphidiidae) Ge2 sp1

SP Clynotis? albobarbatus

PL Eriachne benthami

PL Gyrostemon ramulosus

SP (Salticidae) U16 sp2

SP Neosparassus sp7

PL Chorizema racemosum

PL Menkea villosula

$\mathrm{R}$ Ctenotus calurus

$\mathrm{R}$ Ctenotus hanloniB

$\mathrm{R}$ Ctenophorus rubensB

$\mathrm{R}$ Ctenotus pantherinus

$\mathrm{R}$ Ctenotus iapetus

M Sminthopsis youngsoni

R Eremiascincus fasciolatus

PL Pityrodia loxocarpa

R Ctenophorus clayi

$\mathrm{R}$ Ctenotus rufescens

R Menetia surda cresswelli

$R$ Ctenotus piankai

PL Plectrachne rigidissima

R Menetia greyii(c)

PL Eremophila setacea MS

PL Sida rohlenae

Assemblage-5

B Australian Ringneck

B Grey Butcherbird

B Spiny-cheeked Honeyeater

SC Urodacus hartmeyeri

B Common Bronzewing

B Rufous Whistler

B Grey Shrike-thrush

B Grey Fantail

B Broad-tailed Thornbill

SP Forsterina sp1

SP Opopaea sp2

SP Lycosa sp17

SC Urodacus armatus

B Splendid Fairy-wren

$\mathrm{R}$ Ctenophorus scutulatus

$\mathrm{R}$ Lerista connivens

$\mathrm{R}$ Heteronotia binoei

$\mathrm{R}$ Lerista muelleri(b)

SP Lycosa sp2

PL Waitzia nitida

SP Ocrisiona leucocomis

SP Lycosa bicolor

B Willie Wagtail

B Variegated Fairy-wren

B White-browed Babbler

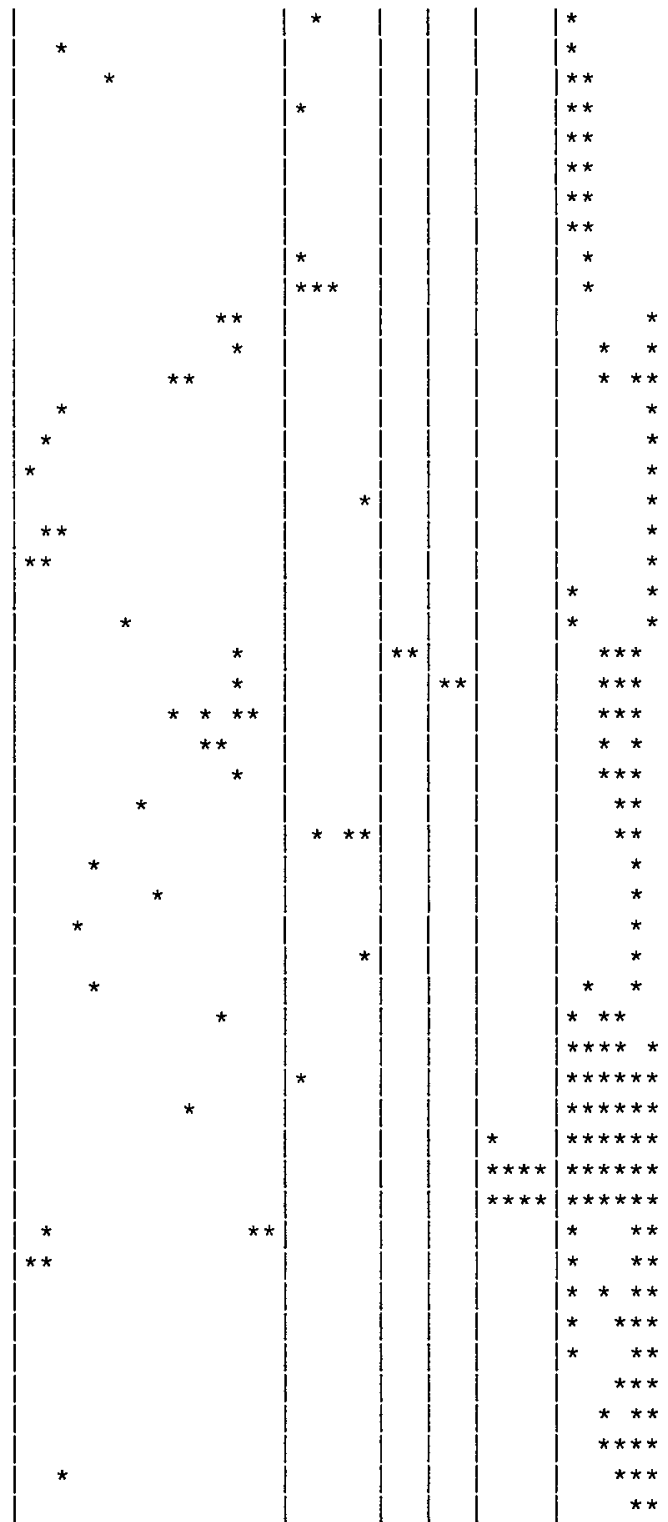

1

23

4

$5 \quad 6$

$899 \quad 10 \quad 11$

BBBBBCCCCPPPC | B | CN | BBBBPMMMMMNMWWWWW / NNNNN | GGGGG | KKKKKMMMM | NNNZZZ | EE | ZZ |P

BBBBBUUUUEEEU |O UA 10000 EDDDRDADOOOOO | EEEEE | JJJJJ | EEEEERRRR | AAAUUU | LL / UU |E 1324523452536
2

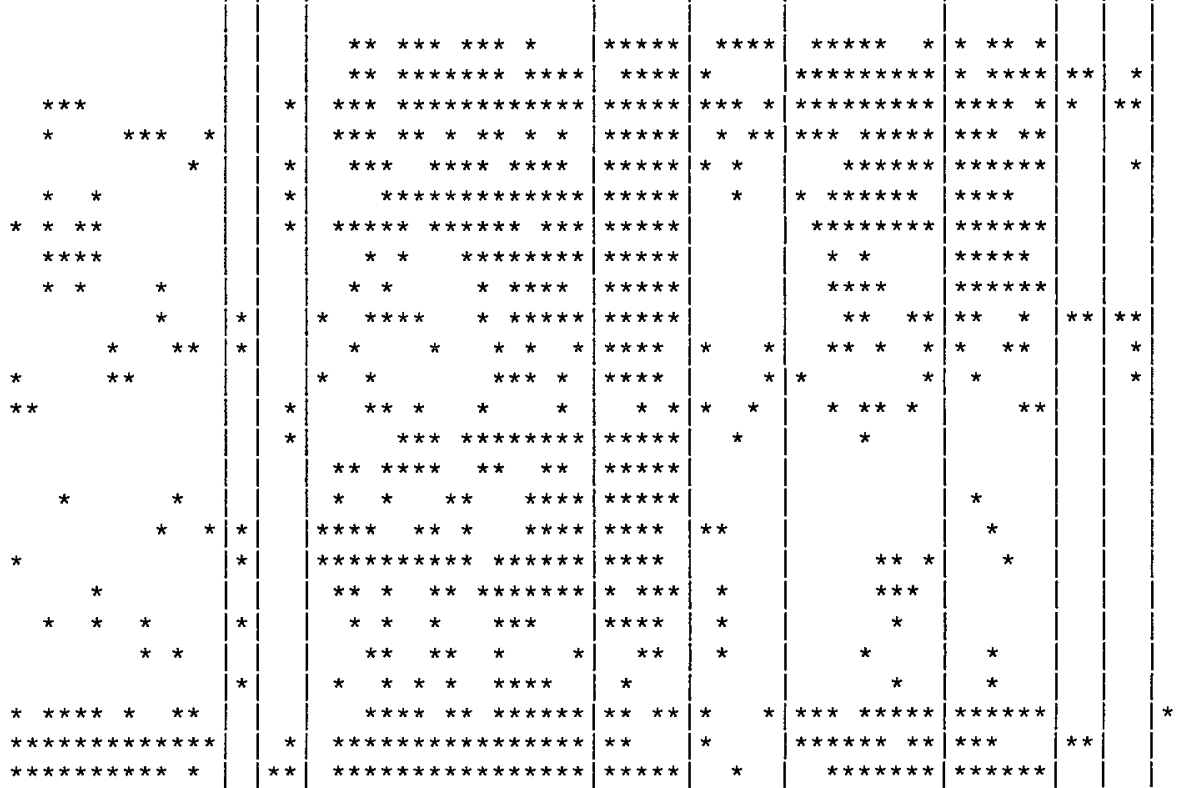


Figure 12 (cont.)

$\mathrm{B}$ Crested Bellbird

$\mathrm{R}$ Gehyra variegata

B Singing Honeyeater

C Cormocephalus turneri

C Scolopenara morsitans

SP Grayenulla australensis

C Ethmostigmus rubripes

SP Myrmopopaea spp

C Scolopendra laeta

M Pseudomys hermannsburgensis

$B$ Western Wedgebil1

B Little Crow

PL Calandrinia polyandra

R Nephrurus levis

$M$ Notomys alexis

SP (Iycosidae) Genus2 sp2

B Crested Pigeon

B Zebra Finch

$B$ Tree Martin

C Allothereua spp

B Horsfield's Bronze Cuckoo

$R$ Pogona minor

SP Miturga sp2

B Pied Honeyeater

C Geophilida spp

SC Lychas sp3

B Black-eared Cuckoo

$B$ Budgerigar

$B$ White-winged Triller

B Black-faced Woodswallow

PI Aristida holathera

SP Opopaea $\operatorname{spl}$

SP (Salticidae) U05 sp1

$B$ Pied Butcherbird

PL Euphorbia drummondii

PL Solanum lasiophyllum

PL Eragrostis lanipes

PL Murchisonia volubilis

PL Cassia chatelainiana

SP Zebraplatys keyserlingi

SP Miturga sp1

B Redthroat

$\mathrm{R}$ Lerista uniduo

SP Lycosa sp5

$\mathrm{R}$ Lerista macropisthopus

$\mathrm{R}$ Diplodactylus squarrosus

PL ptilotus polystachyus

$R$ Menetia greyii(a)

SP Bianor sp2

PL Ptilotus gaudichaudii

PL Ptilotus obovatus

PL Chenopodium gaudichaudianum

B Chestnut-rumped Thornbil1

B Galah

B Red-capped Robin

SC Lychas sp1

C Arthrorhabdus paucispinus

$\mathrm{R}$ Ctenotus schomburgkii

$\mathrm{R}$ Ctenophorus reticulatus

PL Eragrostis dielsii

SP Lycosa sp4

PL Crassula colorata

PL Brachyscome iberidifolia

PL Erodium cygnorum

PL Pimelea microcephala

PL Goodenia berardiana

PL Rhagodia latifolia

PL Acacia sclerosperma

PL Tetragonia diptera

PL Acacia tetragonophylla

SC Lychas sp2

PL Enchylaena tomentosa

PL Paractaenum novae-hollandiae

C Ethmostigmus curtipes

PL Sida calyxhymenia

PL Stylobasium spathulatum

$\mathrm{R}$ Moloch horridus

B Masked Woodswallow

SP Lycosa sI1

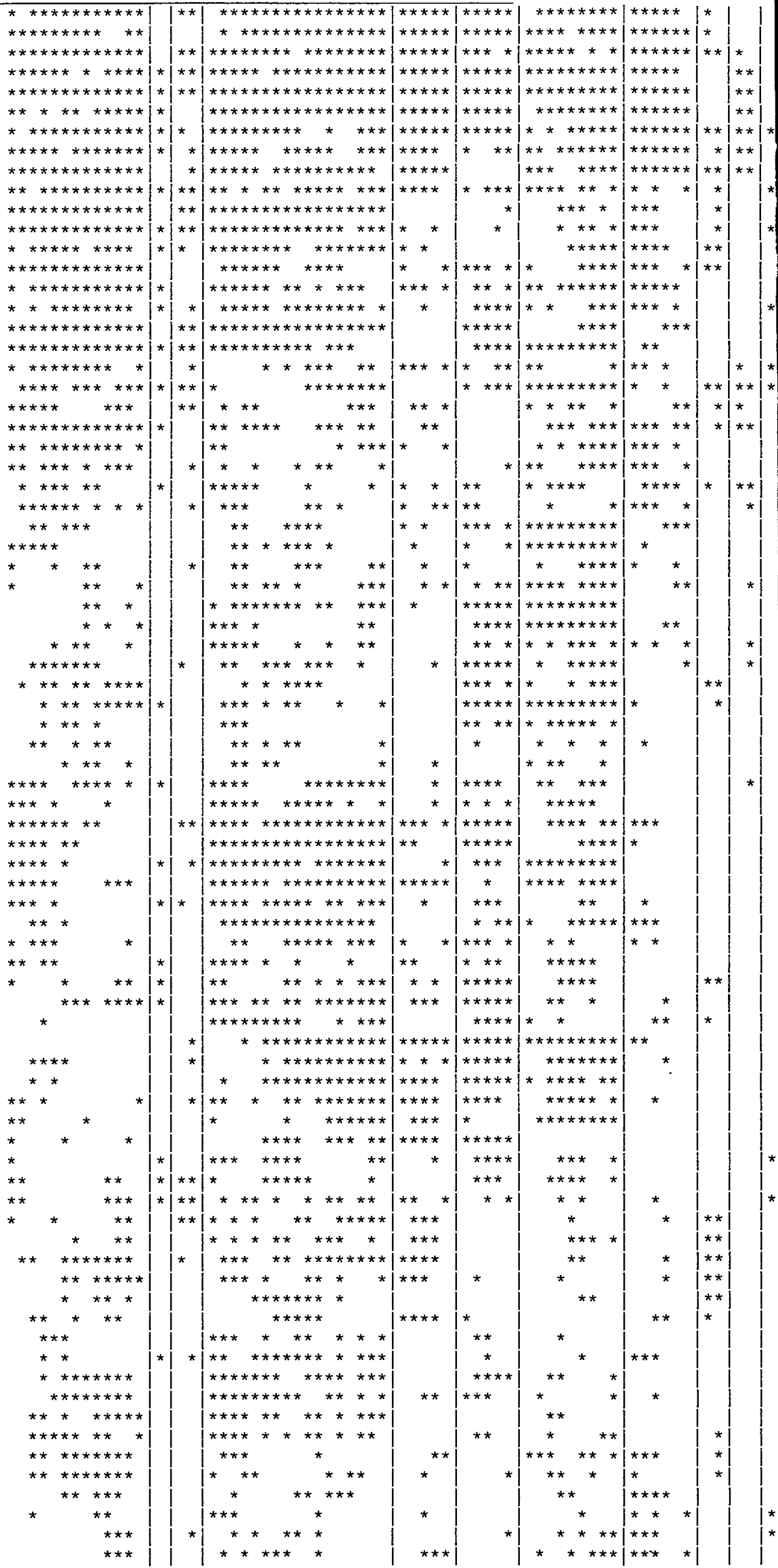


Terrestrial Biodiversity

B White-fronted Honeyeater

SP (Lycosidae) Genus2 sp1

SP Grymeus sp6

SP Gamasomorpha sp1

SP Lycosa sp13

SP Grymeus sp1

SP Lycidas sp2

SP Lycosa sp8

SP (Salticidae) U02 $\mathrm{sp} 1$

PL Triglochin calcitrapum

SP (Salticidae) U04 sp1

PL Eremophila maitlandii

PL Rhyncharrhena linearis

PL Porana sericea

SP Heteropoda kalbarri

PL Chthonocephalus tomentellus

R Strophurus strophurus

B White-winged Fairy-wren

$\mathrm{SC}$ Isometroides vescus

SP Opopaea sp3

PL Cenchrus ciliaris

PL Euphorbia boophthona

PL Nicotiana occidentalis

SP Wandella sp5

PL Brachyscome cheilocarpa

SP Lycosa sp20

SP Bianor sp1

PL Euphorbia australis

PL Heterodendrum oleifolium

Assemblage- 6

B Brown-headed Honeyeater

B Grey-fronted Honeyeater

PL Bursaria occidentalis

PL Plectrachne bromoides

$R$ Ctenotus alleni

PL Acacia Iongispinea

PI Tricoryne aff. corynothecoides

B Malleefowl

PL Eucalyptus eudesmioides

PL Lamarchea hakeifolia var. brevi

PL Stenanthemum complicatum

PL Pityrodia verbascina

$\mathrm{R}$ Ctenophorus maculatus maculatus

PL Calothamnus borealis

PL Grevillea eriostachya

SP Isopedella saundersi

SP Lycosa sp23

SP Badumna insignis

SP Neosparassus sp4

SP (Salticidae) U05 sp2

PL Acacia subrigida

PL Lasiopetalum oppositifolium

PL Melaleuca aff. quadrifidus

PL Eremophila occidens MS

PL Wurmbea cernua

B Fan-tailed Cuckoo

PL Halgania cyanea

SP Lycosa forresti

R Lerista kendricki

PL Baeckea sp. Nanga (ASG11346)

PL Acacia latipes

SP (Salticidae) U12 spl

PL Acacia spathulifolia

PL Lechenaultia linarioides

PL Alyxia buxifolia

PL Melaleuca aff leiopyxis

SP Gmogala sp2

PL Allocasuarina acutivalvis

SP (Salticidae) (Unidentati_14) sp1

Assemblage-7

B Chestnut Quail-thrush



$\begin{array}{llllllll}2 & 3 & 4 & 5 & 6 & 7 & 8 & 9\end{array}$

BBBBBBBCCCEGGGGGKKKMMMMMMMNPPPPWWWWWZ | BN | KMMZ | BPBZ | NNNN | NNNNZ / CZE |CCK / M BBBBOOOUUULJJJJJEEEDDDDDRRAEEEEOOOOOU | BE | ERRU | OEOU | AEEE | AAEAU | UUL |UUE |R \begin{tabular}{ll|l|l|l|l|l|l|l|l|l|l|l|l|l|l|l|l|l|l|}
1345245146212345345123453511245123452 & 22 & 2245 & 1334 & 2345 & 34153 & 211 & 351 & 1
\end{tabular}

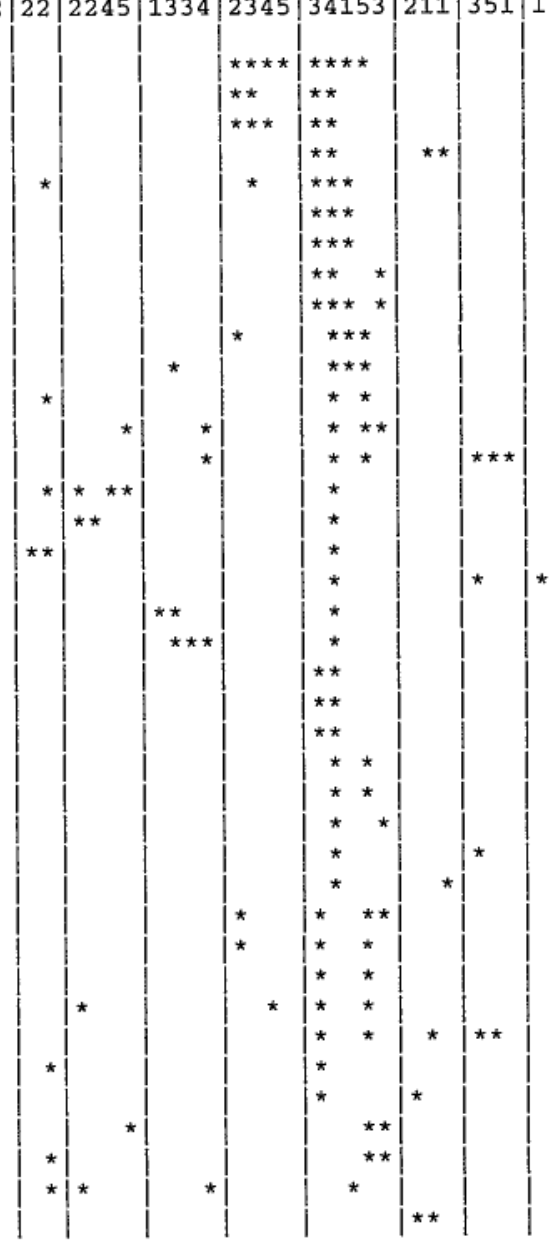

23

4

5

6

BBBBBBBCCCCEGKKPZZZZ | BEGGPPMPZ | KWN | MMWNNNNNNWWPW | BBNMMNNKMMCMKMGG $\mid$ CM BBBBBOOUUUULJEEEUUUU | OLJJEEDEU | EOA DDOAEEEEEOOEO|OOARRAAEDRURERJJ |UD $12345121246141211245|321523153| 441|4512134523542| 4543435332315523 \mid 52$ 
Figure 12 (cont.)

PL Solanum orbiculatum

PL Acacia coolgardiensis effusa

PL Leucochrysum fitzgibbonii

B Yellow-throated Miner

PL Calandrinia lehmanni

PL Uldinia ceratocarpa

B Mistletoebird

PL Marsdenia australis

B Weebill

PL Monachather paradoxus

PL Chthonocephalus pseudevax

PL Wurmbea densiflora

PL Thysanotus manglesianus

B Red-tailed Black Cockatoo

PL Goodenia occidentalis

PL Trachymene cyanopetala

PL Eucalyptus mannensis

PL Calandrinia corrigioloides

PL Ptilotus drummondii

SP Lycidas sp5

PL Synaptantha tillaeacea

PL Gnephosis tenuissima

PL Brunonia australis

SP Myrmarachne spl

PL Velleia hispida

SP Lycosa sp15

PL Actinobole uliginosum

SP Zebraplatys sp 3

PL Plantago aff. hispidula

PL Grevillea paradoxa

PL Podolepis canescens

PI Acacia roycei

PL. Gnephosis eriocephala

PI Poranthera microphylla

SP (Salticidae) U13 spI

PL Centrolepis drummondiana

PI Comesperma integerrimum

PL Callitris glaucophylla

PL Gilberta tenuifolia

PL Trachymene ornata

PL Lysiana casuarinae

B Golden Whistlex

B Western Gerygone

PL Lawrencella davenportii

R Diplodactylus pulcher(a)

B Varied Sittella

SP (Salticidae) U16 sp1

PL Eremophila oldfieldii

PL Ptilotus stirlingii

Assemblage-8

B Brown Songlark

$B$ White-fronted chat

SP Hadrotarsus sp1

PL Scaevola crassifolia

PI Frankenia pauciflora

PI Zygophyllum ammophilum

PI Rhodanthe humboldtiana

PI Acacia ramulosa

PL Alectryon oleifolius

SP Genus 3 sp1

SP Opisthoncus sp2

PL Carpobrotus dioica MS

PL Rhodanthe stricta

PL Didymanthus roei

PI Cyperus bulbosus

PL Millotia myosotidifolia

B Orange Chat

PL Atriplex paludosa moquiniana

B Samphire Thornbill

B Yellow White-eye

PL Frankenia aff. pauciflora

PL Triglochin centrocarpum

PL Eragrostis pergracilis

PL Podolepis gardneri

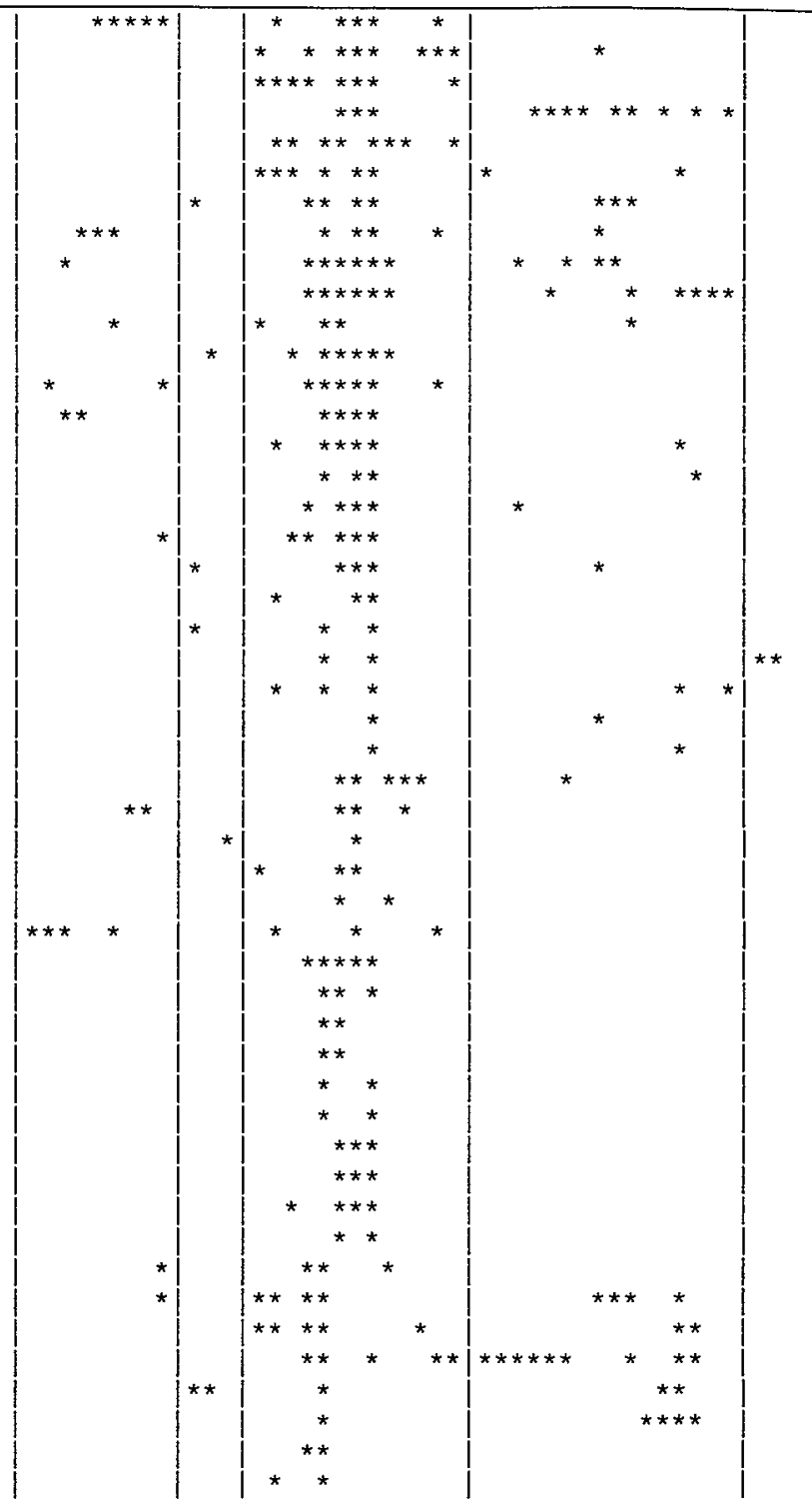

BP | BBBBCPN | BKWC | P | CMECE | BBBBCCGGGGGKKKKMMMMMMMMMNNNNNNNNNPPWWWWZZZZZ

BE | BBBOUEA | BEOU | E ] UDLUL | OOOOUUJJ J JJEEEEDDDDRRRRRAAAAEEEEEEEOOOOUUUUU $15|3542111| 2412|3| 33162 \mid 13454512345123512451234523451234524234512345$ 
PL Gunniopsis septifraga PL Lawrencia viridigrisea SP (Desidae) Genus5 spl PL Zygophyllum compressum PL Halosarcia halocnemoides PL Sondottia glabrata PL Swainsona kingii $\mathrm{PL}$ Halosarcia indica SP (Salticidae) U03 sp1

\section{Assemblage-9}

R Tympanocryptis parviceps PL Acanthocarpus robustus PL Podotheca gnaphalioides PL Stipa crinita

PL Waitzia suaveolens PL Lepidium puberulum

$\mathrm{PL}$ Olearia aff axillaris

PL Poa drummondiana

PL Triglochin trichophorum

Assemblage-10

$\mathrm{R}$ Ctenotus hanloni(a)

PL Triodia pungens

PL Brachysema macrocarpum

PL Daviesia hakeoides

PL Haloragis gossei

SP Fissarena spl

PL Acacia coriacea coriacea

PL Scaevola sericophylla

PL Triodia basedowii

SP Grayenulla sp2

$\mathrm{R}$ Menetia greyii(b)

PL Dampiera incana

SP Simaethula spl

R Strophurus rankini

PL Stackhousia muricata

PL Acacia chartacea

PI Diplopeltis intermedia

PI Goodenia triodiophila

PL Scaevola thesioides

PL Olearia dampieri dampieri MS

Assemblage-11

1

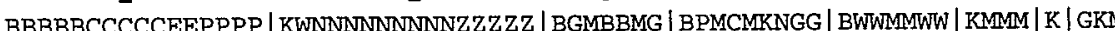
BBBBBUUUUULLIEEEE EOEEEEAAAAEUUUUU |OJDOODJ |OERUDEAJJ |OOODDOO|ERRR |E J JER $1245326345122354|2113452345212453| 1244515|214123114| 3453523|1312| 5 \mid 345$
B Laughing Turtle-Dove
SP Lycosa mainae
PL Beyeria cinerea
PL Eremophila glabra
PL Danthonia caespitosa
SP Neosparassus sp6
PL Solanum oldfieldii
SP Wande11a sp2
B Thick-billed Grasswren
R Tiliqua rugosa
SP Lycosa sp6
R Lerista varia
$\mathrm{R}$ Lerista praepedita(b)
PL Calandrinia liniflora
SP Wandella spl
PI Daucus glochidiatus
SP Deinopis spl
PL Eragrostis barrelieri
PL Wurmbea inframediana
PL Erodium cicutarium
PL Triodia plurinervata
SP Matilda spl
PL Urospermum picroides
PL Atriplex cinerea
SP Wandella sp4

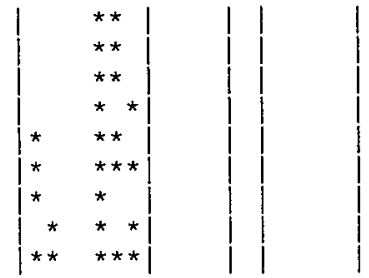

1

234

BBBBBBBBBBCCGGGGGKKKKKMMMMMMMMMMNNNNNNNNNPPPPPWWWWWZZZZ /CCC $|C Z E E| N$ BBBBBOOOOOUUJJ J J JEEEEEDDDDDRRRRRAAAAEEEEEEEEEEOOOOOUUUU | UUU |UULI A $1234512345121234512345123451234513451234512345123451345|345| 6212 \mid 2$

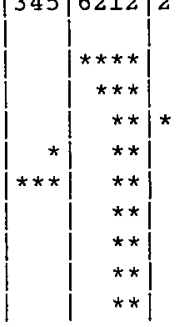

1

2345656 BBBBBBBBBCEGGGGGKKMMMMMMMMMNNNNNNNNNPPPPPWWWWWZZZZ $|\mathrm{B}| \mathrm{E}|\mathrm{z}| \mathrm{CCCCC}|\mathrm{KKN}| \mathrm{KM}$ BBBBBOOOOULJJJJJEEDDDDDRRRRAAAAAEEEEEEEEEOOOOOUUUU|O|L U UUUUU| EEE |ER (1)
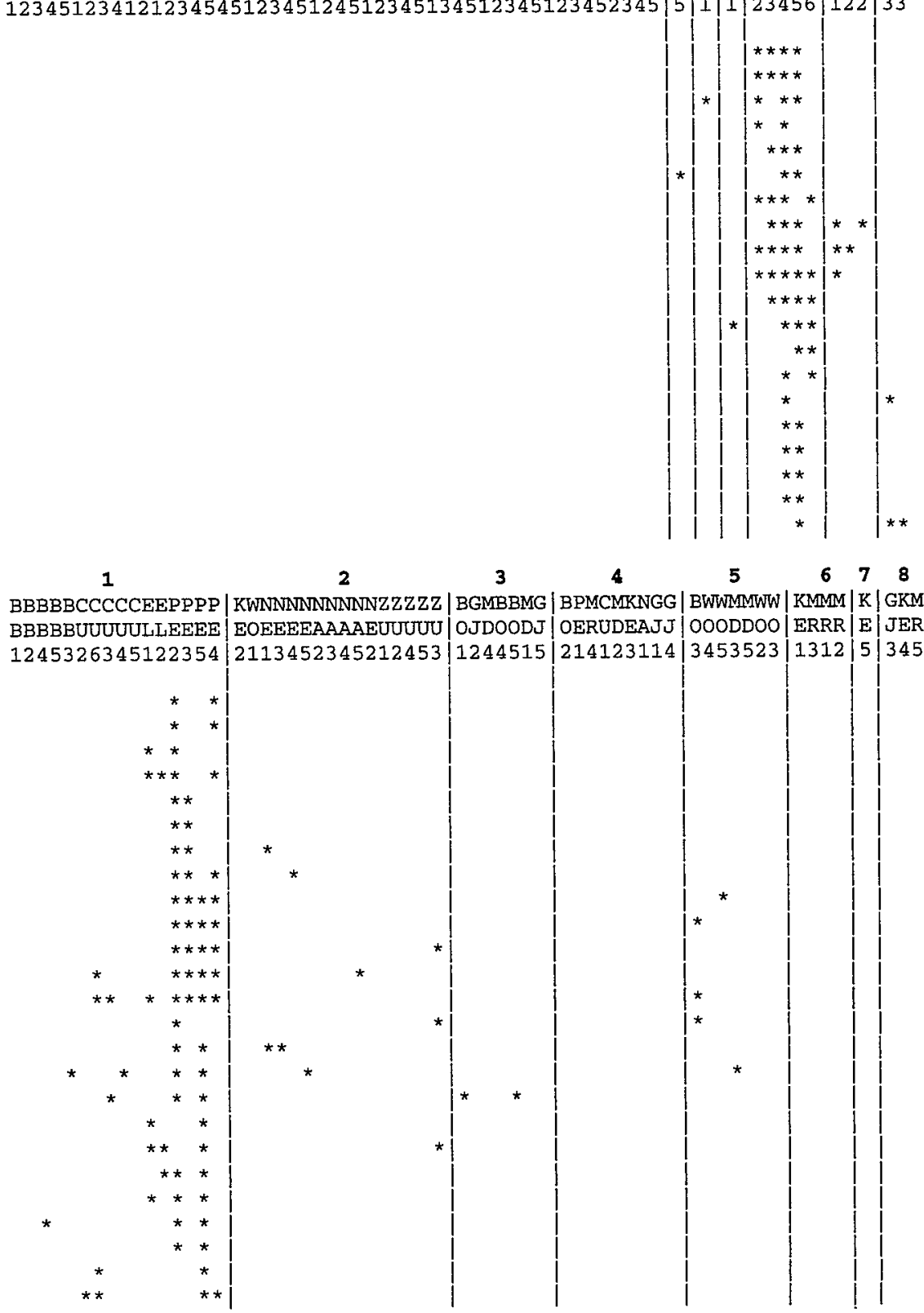
Figure 12 (cont.)

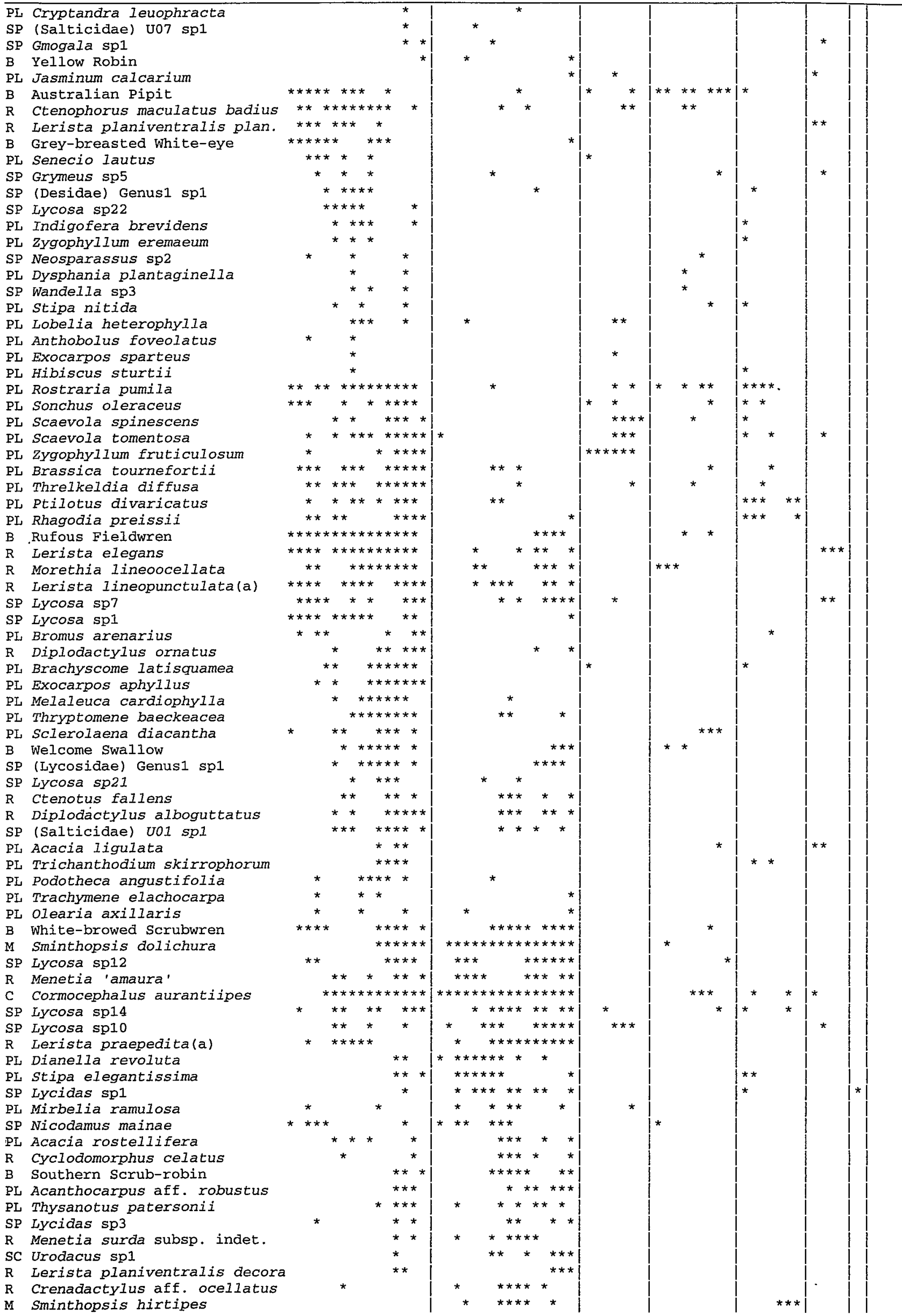


Assemblage - 12

B Australian Raven

SP Uliodon tarantulinus

B Brown Honeyeater

PL Calytrix brevifolia

PI. Ecdeiocolea monostachya

SP Forsterina sp2

A Arenophryne rotunda

M Pseudomys albocinereus

$R$ Diplodactylus spinigerus spinig.

PL Hibbertia conspicua

PL Persoonia acicularis

SP Margaromma sp1

SP Miturga agelenina

PL Melaleuca aff. nesophila

SP (Salticidae) 009 sp1

B Pallid Cuckoo

PL Banksia ashbyi

PL Banksia sceptrum

PI Geleznowia verrucosa

SP Grymeus sp3

PL Loxocarya aspera MS

PL Melaleuca acerosa

PL Grevillea annulifera

PL Plectrachne danthonioides

PL Scholtzia sp. Folly Hill

PL Hibbertia racemosa

PI Hibbertia subvaginata

PL Opercularia spermacocea

PL Melaleuca conothamnoides

PL Melaleuca scabra

PL Mesomelaena preissii

$R$ Cryptoblepharus carnabyi

$R$ Ctenotus australis

PI Conostylis stylidioides

PL Hibbertia pungens

B Tawny-crowned Honeyeater

PI Calothamnus blepharospermus

PI Eremaea ebracteata

PL Stylidium macrocarpum

PI Stylidium repens

PI Lysinema ciliatum

PI Neurachne alopecuroidea

PI Petrophile brevifolia

PL Schoenus clandestinus

PI Boronia coerulescens

PI Brachysema aphyllum

PI Monotaxis Iurida

PL Petrophile semifurcata

PL Scaevola canescens

$\mathrm{PL}$ Acacia cavealis MS

PL Drosera stolonif. stolonifera

PL Conospermum microflorum

PI Lepidobolus preissianus

B Blue-breasted Fairy-wren

PL Phymatocarpus porphyrocephalus

PL Drosera stolonifera humilis

PL Malleostemon sp. Cooloomia

PI Mesomelaena pseudostygia

PL Leucopogon cordifolius

PL Cassytha aurea

SP Neosparassus sp3

PL Acacia blakelyi

PL Actinostrobus arenarius

PL Allocasuarina campestri

PI Calytrix strigosa

PL Leucopogon cucullatus

PL Lyperanthus nigricans

PL Tetraria microcarpa

$\mathrm{PL}$ Thryptomene denticulata

BBBBBCCGGGGGKKKMMMMMMMMNNPPPPWWWW | BC | BBBCEEBCCPKNNKNNMNW| ZZZZZ |MNNN BOOOOUUJJJJJEEEDDDDRRRRAEEEEEOOOO BU | BBOULLBUUEEAAEAERAO UUUUU | DEEE

$123451412345245124512451512452345|22| 3516124353324132351|12453| 3413$

5

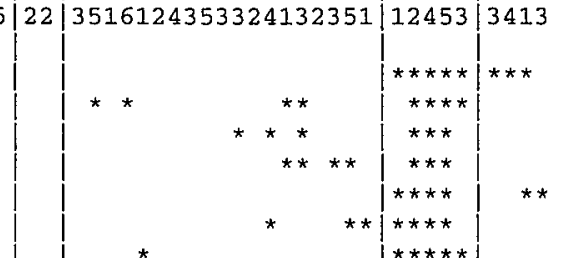

$\star *$
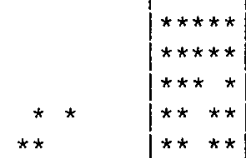

**




Figure 12 (cont.)

Assemblage-13

M Tarsipes rostratus

M Sminthopsis granulipes

PL Amphipogon turbinatus

PL Boronia purdieana

PL Cassytha racemosa

PL Conostylis aculeata

PL Dryandra borealis borealis

PL Gompholobium tomentosum

PL Grevillea preissii

PL Hibbertia spicata spicata

PL Patersonia occidentalis

PL Pimelea leucantha

PL Pityrodia oldfieldi

PL Stylidium elongatum
BBBBBBBBBBCCCCCCEEGGGGGKKKKKMMMMMMMMMMNNNNNNNNNPPPPPWWWWWZZZ $\begin{array}{r}2 \\ \text { BZZ }\end{array}$ separately (cf. McKenzie et al., 1989, 1991a; McKenzie and Belbin, 1991).

As expected, we found that geographical patterns in the occurrence of the various assemblages were related to different sets of environmental attributes. Even so, some attibutes were significant for several assemblages (e.g. precipitation, and soil potassium and phosphorus). Potassium, for instance, is readily leached from soil profiles by rainfall or flood water and provides a sensitive measure of fertility ( $T$. Stoneman, personal communication). As linear predictors, however, attributes such as soil potassium are of little practical value for unsampled sites because data on soil chemistry is only available at a few points in the study area. The tight correlation of soil potassium, 'percent sand' and 'percent silt' with soil shear strength despite six $(10 \%)$ missing values in the shear strength data, suggests that it should be a useful surrogate for field work (Kendall's tau $=0.45$ to $\left.0.48^{* * *}\right)$.

The analyses exposed strong relationships between compositional patterns and environmental attributes for all assemblages. In all 13 cases, both the compositional and richness relationships that emerged from the analysis (Table 5) were consistent with the Australia-wide distributional and habitat characterisations summarised in Figure 3 . Thus, the attribute-sets are unlikely to be artifacts of the quadrat positioning or of the relatively small size of the study area in relation to the size of the geographical ranges of most of the species (see Blackburn and Gaston, 1998).

The geographical pattern in the species richness of each assemblage fitted a Poisson error model, with logarithmic links (Crawley, 1993; Nicholls, 1989), and usually involved the same (or a very similar) set of environmental parameters as did the corresponding compositional analysis (Table
5). Within each assemblage, richness provided a reasonable surrogate for composition because regionally-nested patterns in species composition (cf. Patterson and Brown, 1991; Wright et al., 1998) are visible in each assemblage (see Figure 12). This would be expected in re-ordered matrices, where species have been clustered according to their co-occurrences. That they are not cleanly defined is due, in part at least, to localised patterns in allopatry and sampling errors (e.g. see Rolfe and McKenzie, 2000). Further, well-defined nested patterns in species composition would not be expected for assemblages where richness and composition are influenced by the interaction of several divergent environmental gradient vectors, and a variety of different trophic levels and guilds are represented (Brown, 1995).

In general, climatic as well as soil and/or geographical attributes were required to explain the observed pattern of occurrence of each assemblage across the study area. Thus, patterns in the species composition of the Carnarvon Basin assemblages were being influenced by environmental processes operating at two geographical scales. At the biogeographical scale, patterns were related to the differences between the Eremean and Southwestern biotas, and corresponding to the study area's arid-to-mesic and tropical-to-temperate climatic gradients, but mitigated by coastal effects in northern parts of the study area. At the local scale, patterns were related to topographic, vegetation and/or soil attributes. Previous studies have shown that scale is important in determining which environmental attributes emerge as significant correlates with compositional patterns (Dale, 1983; Whitmore; 1984, Bowers, 1997). Regional studies have usually linked compositional patterns to climatic and/or geological categories (Ashton, 1976; McKenzie et al., 1987b, 1991a, 1992, 
1994; McKenzie and Rolfe, 1995), whereas the importance of topographic setting and lithology have emerged from more geographically restricted studies (Whitmore, 1984).

In our study area, the overt patterns of compositional variation that are usually referred to as patchiness or regional heterogeneity (Weiher and Keddy, 1995) could be explained numerically in terms of attributes of the physical environment. Thus, our results are consistent with the landscape paradigm proposed by Pastor et al. (1997), that spatial heterogeneity (patchiness) is a template to which organisms respond as well as an "emergent feature of their collective responses".

While axes of habitat heterogeneity can be separate or totally coupled and confounded by species responses to the heterogeneity (Bowers, 1997), the question of scaling adds further to the complexity of landscape ecology (Bowers, 1997; MacNally and Quinn, 1997). To expose these patterns for reserve system design and other aspects of wildlife management, we need to measure attributes of the environment that reflect processes at scales that fit the organisms' responses. For instance, a particular response-scale was significant in determining assemblage composition in the region's insectivorous bat guild (McKenzie and Muir, 2000). To explain the biodiversity patterns defined herein, we had to invoke a much wider range of attributes at a greater range of scales. Furthermore, localised patterns of allopatry among closely related species belonging to the more diverse genera, and unevenness in taxonomic discrimination within different taxa, were additional sources of variation (Aplin et al., in press; McKenzie et al., 2000b). In combination with contemporary theory, our results indicate that the Carnarvon Basin reserve system will need to sample the geographical extent of the various climatic and soil gradients identified by the analyses, if evolutionary processes are to be protected therein.

Another issue of immediate concern is the premise that a particular sub-set of the biota, such as the flora, can be used as a reliable surrogate for spatial patterns in biodiversity. The question of whether spatial patterns in the biota coincide across different phylogenetic groups, termed congruence, has usually been addressed in terms of patterns in species richness (e.g. Howard et al., 1998) rather than composition. As with richness, available compositional studies have usually shown that different types of organisms show different geographical patterns of occurrence (e.g. Yen, 1987; Solem and McKenzie, 1991; Ferrier and Watson, 1996; Michaels and Mendel, 1998; but also see Oliver et al., 1997). Our comparison of compositional patterns in seven types of organism shows that each contributed significant amounts of information to our description of the biodiversity pattern. While our result should be treated with caution (because our approach is exploratory rather than experimental), it is not surprising for several reasons.

- The substantial physiological differences between plants and animals, homeotherms and heterotherms, etc, imply very different responses to environmental gradients.

- Guild boundaries do not necessairily conform to taxonomic boundaries (Adams, 1985). For instance, small co-occurring predators such as dasyurids, birds, spiders, scorpions, centipedes, bats, reptiles and frogs partition similar food resource axes, and show patterns of species replacement in geographical space.

- The diversity of prey species at sites is influenced by predation (e.g. Spiller and Schoener, 1998).

Pimm and Lawton (1998) point out, "... we still do not have a theoretical understanding of why the geographical patterns of hotspots, rarity, and complementarity are so different among taxa. Although at large scales distinct biogeographic realms are apparent, within these, nature apparently plays dice with distributions." In identifying aspects of pattern and complexity in biodiversity, macroecological studies such as ours are a first step towards a rigorous understanding of the mechanisms that cause the patterns (Brown, 1995; Blackburn and Gaston, 1998).

We conclude that reserve selection procedures which are based on only one or two types of organism will produce distorted outcomes, although cross-taxon congruence in between-site complementarity (Howard et al., 1998) is likely to offset this problem at biogeographical scales. The distortion is likely to operate at local scales, affecting the representativeness rather than comprehensiveness (sensu Woinarski and Norton, 1993) of reserve systems.

\section{ACKNOWLEDGEMENTS}

P. Boglio, A.A. Burbidge, A.H. Burbidge, A. Desmond, P.J. Fuller, N. Hall, R.E. Johnstone, M.N. Lyons, B. Maryan, W.P. Muir, R. Smith, and P. Stone assisted in the sampling program. M.N. Lyons prepared the map and P. Gioia ran the computer package ANUCLIM to generate the climatic data-set. We thank A.O. Nicholls and M.R. Williams for statistical advice, and two anonymous referees for their comments on the manuscript.

Funding was provided by the Commonwealth through the National Reserves System Co-operative Program of the Australian Nature Conservation Agency (now Environment Australia), the Western Australian Department of Conservation and Land Management and the Western Australian Museum. 


\section{REFERENCES}

Adams, J. (1985). The definition and interpretation of guild structure in animal communities. Journal of Animal Ecology 54: 43-59.

Aplin, K.P., Adams, M. and Cowan, M.A. (in press). Systematics and biogeography of the herpetofauna of the Carnarvon region of Western Australia. Records of the Western Australian Museum Supplement.

Ashton, P.S. (1976). Mixed dipterocarp forest and its variation with habitat in Malayan lowlands: a reevaluation at Pasoh. Malay Forester 39: 56-72.

Austin, M.P. (1984). Problems of vegetation analysis for nature conservation. In K. Myers and C.R. Margules (eds), Survey Methods for Nature Conservation: 1, 101130. CSIRO Division of Water and Land Resources, Canberra.

Austin, M.P. (1991). Vegetation theory in relation to costefficient survey. In C.R. Margules and M.P. Austin (eds), Nature Conservation: Cost Effective Biological Surveys and Data Analysis, 17-22. CSIRO Division of Wildlife and Ecology, Canberra.

Austin, M.P. and McKenzie, N.J. (1988). Data analysis. In R.H. Gunn, J.A. Beattie, R.E. Reid and R.H.M. van der Graaff (eds), Australian Soil and Land Survey Handbook: Guidelines for Conducting Surveys, 210-232. Inkata Press, Melbourne and Sydney.

Austin, M.P. and Heyligers, P.C. (1989). Vegetation survey design for conservation: gradsec sampling of forests in north-eastern New South Wales. Biological Conservation 50: 13-32.

Beard, J.S. (1975). Pilbara. Explanatory Notes to Sheet 5, 1:1000 000 Series. Vegetation Survey of Western Australia. University of Western Australia Press, Nedlands.

Beard, J.S. (1976). Murchison. Explanatory Notes to Sheet 6, 1:1000 000 Series. Vegetation Survey of Western Australia. University of Western Australia Press, Nedlands.

Beard, J.S. (1980). A new phytogeographic map of Western Australia. Western Australian Herbarium Research Notes 3: 37-58.

Belbin, L. (1980). TWOSTEP: a program incorporating asymmetric comparisons that uses two steps to produce a dissimilarity matrix. CSIRO Division of Land Use Research Technical Memorandum 80/9. CSIRO, Canberra.

Belbin, L. (1991). Semi-strong Hybrid Scaling: a new ordination algotithm. Journal of Vegetation Science 2: 491-496.

Belbin, L. (1995). PATN Technical Reference. CSIRO Division of Wildlife and Ecology, Canberra.

Blackburn, T.M. and Gaston, K.J. (1998). Some methodological issues in macroecology. The American Naturalist 151: 68-83.

Bowers, M.A. (1997). Mammalian landscape ecology. Journal of Mammalogy 78: 997-998.

Brown, J.H. (1995). Macroecology. University of Chicago press, Chicago.

Braithwaite, R.W. (1984). Problems of scale, complexity and patchiness in sampling vertebrate fauna. In K. Myers, C.R. Margules and I. Musto (eds), Survey Methods for Nature Conservation: 1,
131-156. CSIRO Division of Water and Land Resources, Canberra.

Burbidge, A.A. and McKenzie, N.L. (1989). Patterns in the modern decline of Western Australia's vertebrate fauna: causes and conservation considerations. Biological Conservation 50: 143-198.

Burbidge, A.H., Johnstone, R.E., Fuller, P.J. and Stone, P. (2000). Terrestrial birds of the southern Carnarvon Basin, Western Australia: contempory patterns of occurrence. Records of the Western Australian Museum Supplement No. 61: 449-464.

Clarke, K.R. (1993). Non-parametric multivariate analyses of changes in community structure. Australian Journal of Ecology 6: 163-174.

Crawley, M.J. (1993). GLIM for Ecologists. Blackwell Scientific Publications, Oxford.

Czekanowski, J. (1932). Coefficient of racial likeness, und durchschnittliche differenz. Anthropologischer Anzeiger 9: 227-249.

Dale, P.E.R. (1983). Scale problem in classification: an application of a stochastic method to evaluate the relative homogeneity of sample units. Australian Journal of Ecology 8: 189-198.

Ehmann, H. (1992). Encyclopedia of Australian Animals: Reptiles. Collins Angus and Robertson, Australia.

Ferrier, S. and Watson, G. (1996). An evaluation of the effectiveness of environmental surrogates and modelling techniques in predicting the distribution of biological diversity. Consultancy Report for Department of Environment, Sport and Territories, Canberra.

Friedel, M.H. and James, C.D. (1995). How does grazing of native pastures affect their biodiversity? In R.A. Bradstock, T.D. Auld, D.A. Keith, R.T. Kingsford, D. Lunney and D.P. Sivertsen (eds), Conserving Biodiversity: Threats and Solutions, 249-59. Surrey Beatty and Sons, New South Wales.

Gibson, N., Keighery, G.J. and Lyons, M.N. (2000). The flora and vegetation of the seasonal and perennial wetlands of the southern Carnarvon Basin, Western Australia. Records of the Western Australian Museum Supplement No. 61: 175-199.

Harvey, M.S., Sampey, A., West, P.L.J. and Waldock, J.M. (2000). Araneomorph spiders from the southern Carnarvon Basin, Western Australia: a consideration of regional biogeographic relationships. Records of the Western Australian Museum Supplement No. 61: 295321.

Hobbs, T.J., Morton, S.R., Masters, P. and Jones, K.R. (1984). Influence of pit-trap design on sampling of reptiles in arid spinifex grasslands. Wildlife Research 21: $483-490$.

Hocking, R.M., Moors, H.T. and van der Graaff, W.J. E. (1987). Geology of the Carnarvon Basin. Geological Survey of Western Australia Bulletin No. 133.

Howard, P.C., Viskanic, P., Davenport, T.R.B., Kigenyl, F.W., Baltzer, M., Dickenson, C.J., Lwanga, J.S., Matthews, R.A. and Balmford, A. (1998). Complementarity and the use of indicator groups for reserve selection in Uganda. Nature 394: 472-475.

Hubert, L. and Arabie, P. (1985). Comparing partitions. Journal of Classification 2: 193-218. 
Jessop, J.P. (1981). Flora of Central Australia. A.H. and A.W. Reed Pty Ltd, New Zealand.

Keighery, G.J., Gibson, N., Lyons, M.N. and Burbidge, A.H. (2000). The flora and vegetation of the southern Carnarvon Basin, Western Australia. Records of the Western Australian Museum Supplement No. 61: 77154.

Koch, L.E. (1981). The scorpions of Australia: Aspects of their ecology and zoogeography. In A. Keast (ed.), Ecological Biogeography of Australia, 873-884. Dr W. Junk bv Publishers, The Hague.

Landsberg, J., James, C.D., Morton, S.R., Hobbs, T.J., Stohl, J., Drew, A, and Tongway, H. (1997). The Effects of Artificial Sources of Water on Rangeland Biodiversity. Final Report to the Biodiversity Convention and Strategy Section of the Biodiversity Group, Environment Australia. Environment Australia and CSIRO, Canberra.

MacNally, R. and Quinn, G.P. (1997). Symposium introduction: the importance of scale in ecology. Australian Journal of Ecology 23: 1-7.

McKenzie, N.L. and Muir, W.P. (2000). Bats of the southern Carnarvon Basin, Western Australia. Records of the Western Australian Museum Supplement No. 61: 465-477.

McKenzie, N.L. and Rolfe, J.R. (1986). Structure of bat guilds in the Kimberley mangroves, Australia. Journal of Animal Ecology 55: 401-420.

McKenzie, N.L. and Belbin, D.L. (1991). Kimberley rainforest communities: reserve recommendations and management considerations. In N.L. McKenzie, R.B. Johnstone and P.G. Kendrick (eds), Kimberley Rainforests of Australia, 453-468. Surrey Beatty and Sons Pty Ltd, Chipping Norton, NSW.

McKenzie, N.L., Belbin, L., Margules, C.R. and Keighery, G.J. (1989). Selecting representative reserve systems in remote areas: a case study in the Nullarbor region, Australia. Biological Conservation 50: 239-261

McKenzie, N.L., Belbin, L., Keighery, G.J. and Kenneally, K.F. (1991a). Kimberley rainforest communities: patterns of species composition and Holocene biogeography. In N.L. McKenzie, R.B. Johnstone and P.G. Kendrick (eds), Kimberley Rainforests of Australia, 423-451. Surrey Beatty and Sons Pty Ltd, Chipping Norton, NSW.

McKenzie, N.L., Robinson, A.C. and Belbin, D.L. (1991b). Biogeographic survey of the Nullarbor district, Australia. In C.R. Margules, and M.P Austin (eds), Nature Conservation: Cost Effective Biological Surveys and Data Analysis, 109-126. CSIRO Division of Wildlife and Ecology, Canberra.

McKenzie, N.L., Halse, S.A. and Gibson, N. (2000a). Some gaps in the reserve system of the southern Carnarvon Basin, Western Australia. Records of the Western Australian Museum Supplement No. 61: 547567.

McKenzie, N.L., Rolfe, J.K., Aplin, K.P., Cowan, M.A. and Smith, L.A. (2000b). Herpetofauna of the southern Carnarvon Basin, Western Australia. Records of the Western Australian Museum Supplement No. 61: 335-360.

McMahon, J.P., Hutchinson, M.F., Nix, H.A. and Ord, K.D. (1995). ANUCLIM Users Guide, Version 1. Centre for Resource and Environmental Studies, Australian National University, Canberra, Australia.

Margules, C.R. and Austin, M.P. (1994). Biological models for monitoring species decline. Philosophical Transactions of the Royal Society of London B 344: 69-75.

May, R.M. (1975). Patterns of species abundance and diversity. In M.L. Cody and J.M. Diamond (eds), Ecology and Evolution of Communities, 81-120. Belknap Press, Cambridge, Massachusets.

Michaels, K. and Mendel, L. (1998). Carabid beetle and vegetation associations in the Tasmanian Eastern Tiers: implications for conservation. Pacific Conservation Biology 4: 240-249.

NAG (1986). The Generalised Linear Interactive Modelling System. Release 4.0 Manual. Numerical Algorithms Group, Oxford.

Nicholls, A.O. (1989). How to make biological surveys go further with generalised linear models. Biological Conservation 50: 51-75.

Oliver, I., Beattie, A.J. and York, A. (1997). Spatial fidelity of plant, vertebrate and invertebrate assemblages in multiple-use forest in eastern Australia. Conservation Biology 12: 822-835.

Paine, R.T. (1980). Food webs: linkage, interaction strength and community infrastructure. Journal of Animal Ecology 49: 667-685.

Pastor, J., Moen, R. and Cohen, Y. (1997). Spatial hererogeneities, carrying capacity, and feedbacks in animal-landscape interactions. Journal of Mammalogy 78: 1040-1052

Patterson, B.D. and Brown, J.H. (1991). Regionally nested patterns of species composition in granivorous rodent assemblages. Journal of Biogeography 18: 395-402.

Payne, A.L., Curry, P.J. and Spencer, G.F. (1987). An inventory and condition survey of the rangelands in the Carnarvon Basin, Western Australia. Technical Bulletin No. 78. Department of Agriculture, South Perth.

Pimm, S.L. and Lawton, J.H. (1998). Planning for biodiversity. Science 279: 1068-1069.

Pizzey, G. (1980). A Field Guide to the Birds of Australia. Collins, Sydney.

Rand, W.M. (1971). Objective criteria for the evaluation of clustering methods. Journal of the American Statistical Association 66: 846-850.

Rolfe, J.K. and McKenzie, N.L. (2000). Comparison of methods used to capture herpetofauna: An example from the Carnarvon Basin. Records of the Western Australian Museum Supplement No. 61: 361-370.

Rosenzweig, M.L. (1992). Species diversity gradients: we know more and less than we thought. Journal of Mammalogy 73: 715-730.

Rosenzweig, M.L. and Abramski, Z. (1986). Detecting density-dependent habitat selection. The American Naturalist 126: 405-417.

Sneath, P.H.A. and Sokal, R.R. (1973). Numerical Taxonomy. The Principals and Practice of Numerical Classification. W.H. Freeman, San Francisco.

Solem, A. and McKenzie, N.L. (1991). The composition of land snail communities in Kimberley rainforest communities. In N.L. McKenzie, R.B. Johnstone and P.G. Kendrick (eds), Kimberley Rainforests of Australia, 
247-263. Surrey Beatty and Sons Pty Ltd, Chipping Norton, NSW.

Somerfield, P.J. and Clarke, K.R. (1995). Taxonomic levels, in marine studies, revisited. Marine Ecology Progress Series 127: 113-119.

Spiller, D.A. and Schoener, T.W. (1998). Lizards reduce spider species richness by excluding rare species. Ecology 79: 503-516.

Strahan, R. (Ed.) (1995). The Mammals of Australia. Reed Books Australia.

Taylor, J.A. and Friend, G.R. (1984). Sampling strategies for fauna surveys. In K. Myers, C.R. Margules and I. Musto (eds), Survey Methods for Nature Conservation: 1, 179-192. CSIRO Division of Water and Land Resources, Canberra.

Tyler, M.J., Smith, L.A. and Johnstone, R.E. (1994). Frogs of Western Australia. Western Australian Museum, Perth.

Warner, R.R. and Chesson, P.L. (1985). Co-existence mediated by recruitment fluctuations: a field guide to the storage effect. The American Naturalist 125: 769787.

Weiher, E. and Keddy, P.A. (1995). Assembly rules, null models, and trait dispersion: new questions from old patterns. Oikos 74: 159-164.

Whitmore,T.C. (1984). Tropical Rainforests of the Far East. Clarendon Press, Oxford.

Wiens, J.A. (1985). Vertebrate responses to environmental patchiness in arid and semi-arid ecosystems. In S.T.A. Pickett and P.S. White (eds), The ecology of Natural Disturbance and Patch Dynamics, 169-193. Academic Press, New York.
Wilson, S.K. and Knowles, D.G. (1988). Australia's Reptiles. A Photographic Reference to the Terrestrial Reptiles of Australia. Collins, Australia.

Woinarski, J.C.Z. and Norton, T.W. (1993). Towards a national system of forest reserves: A discussion paper. Department of Environment, Sport and Territories, Canberra.

Wright, D.H., Patterson, B.D., Mikkelson, G.M., Cutler, A. and Atmar, W. (1998). A comparative analysis of nested sub-set patterns of species composition. Oecologica 123: 1-20.

Wyrwoll, K.-H., Stoneman, T., Elliott, G. and Sandercock, P. (2000). Geoecological setting of the Carnarvon Basin, Western Australia: Geology, geomorphology and soils of selected sites. Records of the Western Australian Museum Supplement No. 61: 29-75.

Wyrwoll, K.-H., Courtney, J. and Sandercock, P. (2000). The climatic environment of the Carnarvon Basin, Western Australia. Records of the Western Australian Museum Supplement No. 61: 13-27.

Yen, A.L. (1987). A preliminary assessment of the correlation between plant, vertebrate and coleoptera communities in the Victorian mallee. In J.D. Majer (ed.), The Role of Invertebrates in Conservation and Biological Survey, 73-88. Western Australian Department of Conservation and Land Management, Perth.

Manuscript received 4 September 1998; accepted 10 March 2000. 